This manuscript has been submitted for publication in Geological Society of London Special Publications. Please note that thus manuscript is yet to undergo peer review. Subsequent versions of this manuscript may have slightly different content. If accepted, the final version of this manuscript will be available via the DOI link to the published version on this website. 


\title{
Thermal evolution and resources of the Bowland Basin (NW England) from apatite fission-track analyses and multidimensional basin modelling
}

\author{
Bhavik Harish Lodhia ${ }^{1,4}$, Adeline Parent ${ }^{2}$, Alastair J. Fraser ${ }^{1}$ \\ Martin Nuemaier $^{1}$, Jan A.I. Hennissen ${ }^{3}$ \\ ${ }^{1}$ Department of Earth Science and Engineering, Imperial College London, South \\ Kensington Campus, SW7 2AZ, UK. \\ ${ }^{2}$ Schlumberger Plc., Ritterstr. 23, Aachen, North Rhine-Westphalia, Germany \\ ${ }^{3}$ British Geological Survey, Keyworth, Nottinghamshire,NG12 5GG, UK. \\ ${ }^{4}$ University of New South Wales, Kensington, Sydney, 2052, Australia, \\ b.lodhia@unsw.edu.au.
}

\begin{abstract}
Once highlighted for having significant shale gas resource potential, the Bowland Basin has been at the centre of both scientific and political controversy over the last decade. Previous shale gas resource estimates range from $10^{3}-10^{1}$ TCF. Repeated events of induced seismicity following hydraulic fracturing operations led to an indefinite government moratorium and abandonment of operations across the mainland United Kingdom. We use apatite fission track analyses to investigate the magnitude and timing of post-Triassic uplift and exhumation. Results indicate maximum paleo temperatures of $90-100^{\circ} \mathrm{C}$ were reached in the stratigraphically younger Sherwood Sandstone. We combine paleotemperature predictions to constrain paleo heat flow and erosion in regional basin models for the first time. Our results indicate variable maximum Late Cretaceous paleo heat flow values of $62.5-80$ $\mathrm{mW} \mathrm{m}^{2}$ and the removal of $800-1500 \mathrm{~m}$ of post-Triassic strata at wells across the basin. Regional 2D basin modelling indicates a gas in-place estimate of $131 \pm 64 \mathrm{TCF}$ for the Bowland Shale. This reduces to a resource potential of $13.1 \pm 6.4 \mathrm{TCF}$, assuming a recovery factor of $10 \%$. These values are significantly lower than previous resource estimates and reflect the highly complex nature of the Bowland Basin and relatively unknown history of post-Triassic uplift, exhumation, and erosion.
\end{abstract}

Keywords: Bowland Basin, Apatite fission track, Basin modelling

Preprint submitted to Geological Society of London Special Publications January 31, 2022 


\section{Introduction}

This paper explores the thermal, uplift and erosional history of the Bowland Basin (NW England) using apatite fission track analyses. We apply these results to define new thermal and erosional histories across the Bowland Basin and estimate shale gas resource potential from 1D and 2D basin and petroleum systems modelling.

\subsection{Geological setting and importance}

The Bowland Basin trends NE-SW and lies between the Askrigg-Bowland High to the north, the Central Pennine High to the southeast and at an elevation of $<500 \mathrm{~m}$ above mean sea level (Figure 1, Gawthorpe, 1986). It is one of several Early Carboniferous extensional basins that extend through Ireland to the Canadian Maritimes, formed by north-south extension associated with the opening of Paleothethys (Guion et al., 2000; Fraser and Gawthorpe, 2003; Dewey, 1982; Torsvik et al., 2002). Fault reactivation, extension and volcanic activity associated with the subduction and closure of the Paleothethys Ocean resulted in basin formation north of the Carboniferous Variscan Front across Central Britain (Timmerman, 2004). Structural, sedimentological, gravity and magnetic data suggest that although the present day structural configuration is mainly a result of compression/transpression during late Carboniferous times, Dinantian tectonics and sedimentation were dominated by normal and transfer fault systems related to regional extensional transtension (Gawthorpe, 1987). The Bowland Basin was exhumed during the Variscan Orogeny, and structurally inverted and folded into NE-SW-trending Caledonian en echelon folds (Arthurton, 1983, 1984; Corfield et al., 1996). Very thick accumulations of Dinantian rocks, comprising carbonates and terrigenous mudstones with rare sandstones $(>2 \mathrm{~km})$ have been reported in the literature (e.g. Earp et al., 1961; Charsley, 1984; Gawthorpe, 1986; Andrews, 2013; Clarke et al., 2018). However, within the basin no pre-Carboniferous rocks are known and the base of the Dinantian sequence is not proven. The youngest rocks in the basin are of Triassic age (Figure 2), with over $200 \mathrm{Ma}$ of missing stratigraphy. 


\subsection{Source rocks of the Bowland Basin}

The main hydrocarbon source rocks in the basin are the regional Bowland Shale group, which comprise of the Pendleian-Arnsbergian Carboniferous post-rift Upper Bowland Shale, Asbian-Brigantian syn-rift Lower Bowland Shale and the Early Carboniferous Bowland-Hodder formation (Figures 1 and 2). With a combined thickness of over $1000 \mathrm{~m}$ in the Bowland Basin, the Bowland-Hodder sequence of shales is one of thickest known potential self-sourced, unconventional hydrocarbon resources in the world. The strata are organic rich with TOC values of between $1-7 \%$, with an average of $2.65 \%$, and organic maturity that ranges from the upper oil window in the higher part of the section to dry gas $(\mathrm{Ro}=2.4 \%)$ in the Lower Bowland Shale (Clarke et al., 2018). The paleogeography of Northern and Central England and deposition of the Bowland Shale was primarily controlled by the progression of the Variscan collision-type orogeny, whereby the Variscan plate cycle controlled the development of syn-rift, post-rift and inversion megasequences from Late Devonian to early Permian times. Sequences developed within these Carboniferous megasequences are primarily controlled by episodic rifting and periodic fault reactivation with eustatic sea-level changes providing only minor control at the subsequence level, mainly observed during the post-rift phase (Fraser and Gawthorpe, 1990). Different paleogeographic environments existed between basement blocks across Northern and Central England during the Carboniferous. For example, during the Late Holkerian - Mid Asbian, the Bowland Basin was flanked to the north and south by regional carbonate highs and dominated by marine-influenced turbidite conditions sourced from the west. The Cleveland Basin in northeast England was dominated by open marine conditions, with rimmed shelf conditions dominating the Staffordshire Basin and West Midlands. By Late AsbianEarly Brigantian times, deep water facies sourced from the west dominated the Bowland Basin, whereas the Cleveland Basin was dominated by carbonate ramp facies and the West Midlands dominated by a drowned carbonate shelf environment (Fraser and Gawthorpe, 2003). Hence, it is important to recognise that age-equivalent Carboniferous shales deposited across Northern and Central England are highly heterogenous and sourced from different paleogeofgraphic regions.

A substantial portion of the literature (e.g. Andrews, 2013) confusingly applies the same age to the different sub-units of the Bowland Shale and assumes the interval to be homogenous across Northern England and the Midlands. However, in reality the highly compartmentalised nature of Northern 
and Central England's sedimentary basins and the differing sources of source rock material feeding into these basins mean that Carboniferous shales across this region of the same age in different basins have variable properties. From Clarke et al. (2018), an approximate value of 3583 sq. miles (or $9281 \mathrm{~km}^{2}$ ) is used for basin area. The tectono- and biostratigraphic history of five wells from across the Bowland Basin assessed in this study are summarised on Figure 2 .

However, across Northern and Central England the Bowland Shale possesses all the source rock properties necessary to produce unconventional shale gas. The Bowland Shale holds a significant shale gas/liquid potential in areas with appropriate geochemical properties. This includes a TOC content of $1-7 \%$, gas-prone organic matter (type II/II kerogen), thickness up to $620 \mathrm{~m}$ and thermal maturity values in the thermogenic gas window across large areas of Northern and Central England (Fraser and Gawthorpe, 1990; Collinson, 1988; Gross et al., 2015, Figure 1).

\subsection{Recent exploration and cessation of hydraulic fracturing operations}

The Bowland Basin has long been a region of economic interest, with Triassic reservoirs sourced from Carbonifeous shales comprising the main play type. Examples include the onshore Formby Oil Field (Falcon and Kent, 1960) and offshore Manx-Furness Basin (Pharaoh et al., 2018). From 1960 - 2000, a number of conventional exploration wells were drilled in the Bowland Basin, including the important Thistleton-1, Hesketh-1, Elswick-1, Swinden-1 and Whitmoor-1 wells (Clarke et al., 2018). The only significant hydrocarbon discovery before 2000 was made at Elswick-1 in the Permian Collyhurst Sandstone, which produced following hydraulic fracturing in 1990. The reservoir trap is a fourway dip closure with cumulative production to date being $0.5 \mathrm{Bcf}$ (billion cubic ft).

Since 2011, several exploration wells have been drilled in the Bowland Basin to target the Bowland Shale for shale gas potential. Preese Hall-1 (2011), Grange Hill-1Z (2012), Preston New Road-1 (PNR-1, 2014) and Preston New Road-2 (PNR-2, 2018) were drilled by Cuadrilla Resources tapped the Lower Bowland Shale. The region is highly structured and a significant number of near-vertical faults make seismic interpretation very difficult (e.g. Anderson and Underhill, 2020). The primary cause of induced seismicity in the region is believed to be reactivation of faults (Nantanoi et al., 2021). Repeated incidents of induced seismicity above the United 
Kingdom's upper limit of $\mathrm{M}_{w}=0.5$ caused operations to be ceased whilst causes were investigated. In November 2019, the UK Government announced an indefinite moratorium on all hydraulic fracturing activities following an incident of induced seismicity $\left(\mathrm{M}_{w}=2.9\right)$ at the Preston New Road site, Lancashire. This major shift in government policy effectively marked the end for onshore UK shale gas operations.

\subsection{History of resource estimates}

Resource estimates for the Bowland Shale vary wildly. Andrews (2013) estimated Gas in Place (GIIP) for the Bowland-Hodder unit across the entire Northern and Central England between 164 - 477 Tcf (Trillion cubic feet). Andrews (2013)'s assessment was based on adsorbed and free gas estimates for US shales, and assumed that all Bowland Shale source rock with a maturity above $1.1 \%$ Ro, had already generated gas. Caudrilla Resources estimated a gas per unit volume of rock in the Bowland Shale ranges from $0.6-1.5$ Bcf per metre per square mile (Clarke et al., 2018). Their assessment indicated oil generation in the Late Carboniferous, prior to Variscan uplift with renewed subsidence through the early Mesozoic resulting in increased maturity and gas generation. Note that this resource estimate refers specifically to the Bowland Basin and not the total area of coverage of the Bowland Shale across Northern and Central England (e.g. Andrews, 2013). Whitelaw et al. (2019) use sequential high-pressure water pyrolysis (HPWP) to replicate petroleum generation and expulsion in uplifted onshore basins and predict the maximum GIIP using oil window and gas window mature UK Bowland Shales. Their method gives an estimated maximum total GIIP of $140 \pm 55$ Tcf. Assuming an economic recovery of $10 \%$, which is unlikely for much of the Lower Bowland Shale due to its depth of over $3000 \mathrm{~m}$, Whitelaw et al. (2019)'s estimate represents a maximum resource estimate of $14 \pm 6$ Tcf, less than 10 times the previous estimate.

Although the future of shale gas exploration in the Bowland Basin looks uncertain, the region presents several important scientific challenges. First, the history of uplift, erosion and paleo heat flow of the region is poorly constrained. These are important parameters that affect the burial and maturation of source rocks and ultimately the generation and timing of migration of hydrocarbons. Previous attempts at estimating resources have been focussed on laboratory analyses and comparisons to analogue data from US shales. However, regional basin and petroleum systems modelling that combine geology at the borehole-scale to geophysics at the basin-scale has never before 
been attempted in the region. Furthermore, there have been no attempts to date to reconcile uncertainties in regional post-Jurassic uplift/erosion using AFTA as an aid for basin modelling in the Bowland Basin. Understanding these processes may shed light on the possibilities beyond unconventional shale gas. This includes potentially using of the Bowland Shale to produce low-carbon resources via $\mathrm{CO}_{2}$-sequestration or investigating its potential as a geothermal reservoir in the naturally-fractured Triassic Sandstone (e.g. Sherwood Sandstone).

\subsection{Missing stratigraphy and paleotemperature}

There have been two major phases of uplift and erosion across the Bowland Basin since its formation. Basin inversion in the foreland of the Variscan orogenic belt occurred in the late Westphalian and was related to events to the south. The climax of inversion occurred in the late Westphalian DStephanian and resulted in extensive uplift and erosion of the Variscan foreland. As a consequence, post-Carboniferous rocks of various ages rest upon Carboniferous rocks with angular unconformity over most of the British Isles, which is evidenced on seismic data throughout the province (Corfield et al., 1996). Estimates of burial and uplift obtained from seismic, vitrinite reflectance and fission track data indicate the removal of 2000 - 2500 m of Late Carboniferous stratigraphy due to Variscan erosion (Fraser and Gawthorpe, 1990). This is evident by the absence of Westphalian/Stephanian strata in wells across the basin (Figure 2). This event is marked by a regional unconformity that separates underlying Carboniferous strata from Permian clastic sediments and is named the Base Permian Unconformity (BPU, Figure 7).

The second phase of uplift and erosion across the region is responsible for the absence of post-Triassic stratigraphy across the majority of the Bowland Basin and continues to the present day. There is around $200 \mathrm{Ma}$ of missing stratigraphy in the Bowland Basin (Figure 2). The evolution of the region from fluvial/lacustrine-marginal marine conditions to its present terrestrial setting is therefore not recorded.

Early application of Apatite Fission Track Analysis (AFTA) to exploration wells revealed early Neogene palaeotemperatures around $110^{\circ} \mathrm{C}$ or more. Further studies in the Irish Sea and adjacent areas, using a combination of AFTA and vitrinite reflectance, indicated at least three additional palaeo-thermal episodes: pre-Permian (> $290 \mathrm{Ma}$ ), Late Permian to midTriassic $(260-220 \mathrm{Ma})$ and Early Cretaceous $(140-110 \mathrm{Ma})$. Other evidence of early paleo-thermal effects, for which timing is only constrained to 

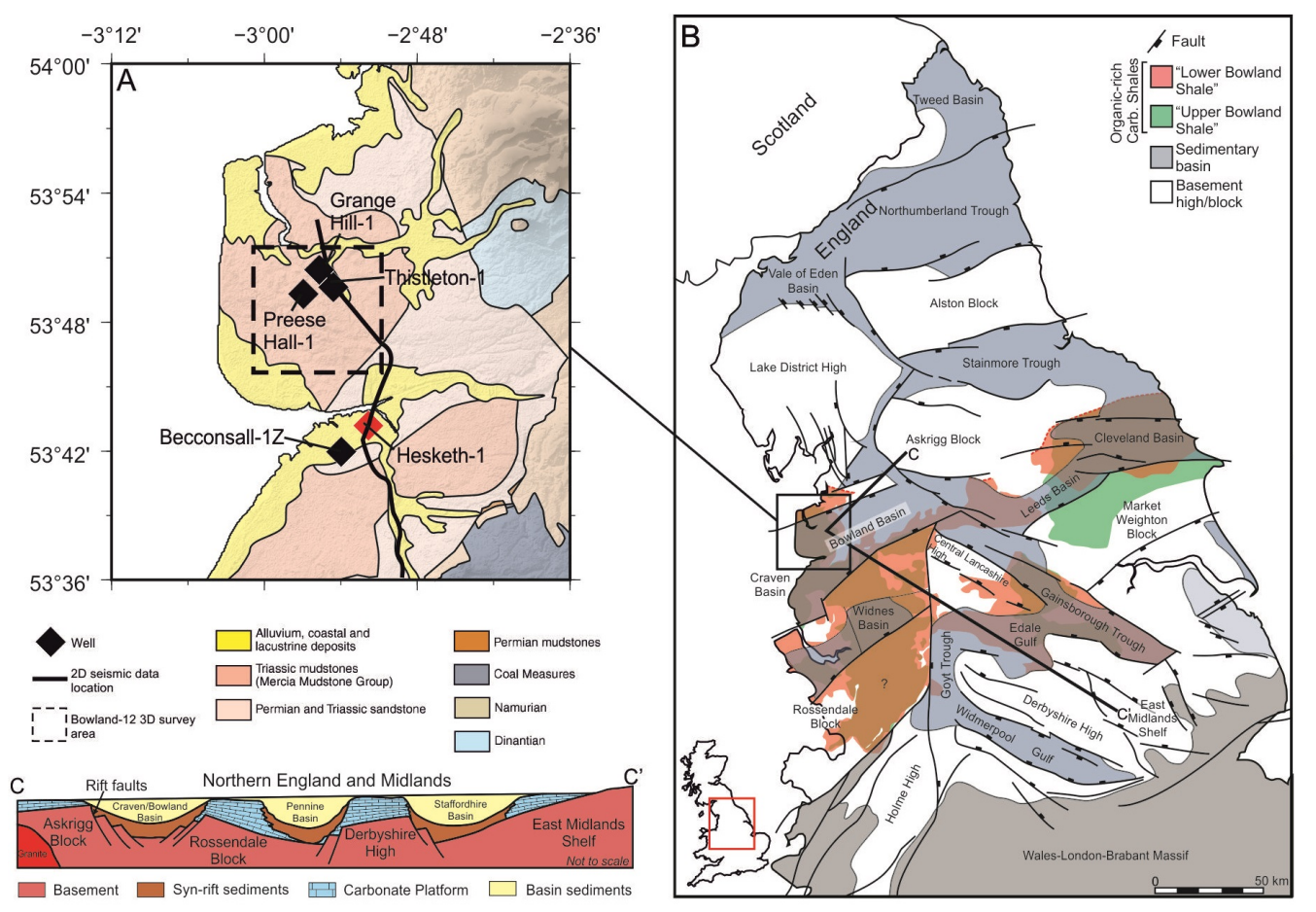

Figure 1: Geological map, study area with data locations and representative cross section. A = Geological map of Bowland Basin (adapted from Donnelly, 2006) with locations of wells and seismic data used in this study. Red diamond = location of well Hesketh1 , used for apatite fission track analyses. Location of region is indicated by the black rectangle on panel $\mathrm{B} . \mathrm{B}=$ Major faults, sedimentary basins and coverage of Bowland Shale formation across Northern and Central England. Distribution of Bowland Shale from Andrews (2013) and positions of faults from Fraser and Gawthorpe (1990). The location of the well Hesketh-1, for which AFTA data is available, is shown by a red diamond. $\mathrm{C}=$ Schematic profile across the Central Province showing the general style of 'blocks' and 'basins' that are typical for Northern England and the Midlands at the end of the Dinantian. This figure is not accurately scaled, either vertically or horizontally. The maximum depth of basinal areas is approx. 500-800 m (adapted from Collinson, 1988) and profile location is given for indicative purposes only. 
the interval 300 - 150 Ma, may reflect these or additional episodes (Green et al., 1997). The Bowland Basin lies on the eastern margin of the larger Permian-Mesozoic East Irish Sea Basin (EISB) with peak hydrocarbon generation from the Bowland source rocks coincident with maximum burial of the system during Late Jurassic-Early Cretaceous times (Pharaoh et al., 2018). AFTA by Holford et al. (2005) revealed several distinct episodes of kilometre-scale exhumation during the Early Cretaceous $(<3 \mathrm{~km})$, Early Palaeogene $(<2 \mathrm{~km})$ and Late Palaeogene-Neogene times $(c .1 \mathrm{~km})$, with the overall magnitude of exhumation in each episode decreasing overtime. Regional Early Cretaceous exhumation appears to be related to incipient Atlantic rifting. Early Palaeogene exhumation was driven by a combination of localized tectonic inversion and regional epeirogenic uplift,although early Palaeogene palaeotemperatures within parts of the Irish Sea basin system are dominated by non-burial-related processes. A final phase of exhumation related to late Palaeogene- Neogene tectonic inversion, uniformly removed c.1 km of section from this region (Holford et al., 2005). Furthermore, mapping of exhumation patterns in the EISB through sonic velocity analyses of overcompacted Upper Triassic shales by Holford et al. (2009) indicated that the sub Quaternary unconformity present across the EISB marks between $1.3-3.3 \mathrm{~km}$ of post-Early Jurassic exhumation.

It is highly probable that the Bowland Basin was also affected by the exhumation and erosion of the EISB. However, there are no previous studies that combine paleotemperature measurements with regional basin modelling in the Bowland Basin. In this study, we use apatite fission track data from Hesketh-1 (Figure 1) for the first time to measure paleotemperatures in the Bowland Basin over the interval of missing stratigraphy and apply this constraint to $1 \mathrm{D}$ and regional 2D basin and petroleum systems modelling.

Basin modelling relies on fitting evolution curves to maturity data, whereby different combinations of uplift/erosion and paleo heat flow can yield results that adequately fit data. As such, in the absence of other geological information it is not possible to determine which combination of uplift, erosion and paleo heat flow are most likely from maturity data alone and presents a significant challenge in the Bowland Basin due to the amount of missing stratigraphy. In this study, we apply AFTA analysis to estimate paleotemperatures of the Triassic Sherwood Sandstone at Hesketh-1 and use this to constrain estimates of post-Triassic erosion at wells across the Bowland basin using 1D basin modelling. Estimates of post-Triassic erosion are used to constrain 2D basin modelling for the first time and to estimate shale gas resource 
potential of the Bowland Basin.

\section{Thermal history from apatite fission track data and application to $1 \mathrm{D}$ basin modelling}

As temperature increases progressively with depth within the lithosphere, paleothermal indicators such as AFTA and vitrinite reflectance (VR) can be used to access the former burial depths of rock units (Green et al., 2002). Sedimentary units are progressively heated during burial and begin to cool at the initiation of exhumation. AFTA and VR data provide quantitative estimates of the temperatures attained by individual rock samples at a palaeothermal maximum, prior to the onset of cooling (Green et al., 1995, 2002). VR data can provide discrete estimates of maximum post-depositional palaeotemperatures, whilst AFTA can provide either upper or lower limits, or a range of values for the maximum palaeotemperature in up to three separate palaeothermal episodes (Bray et al., 1992; Green et al., 2002).

In exhumed basins like those of the Irish Sea, palaeotemperatures derived from AFTA and VR data through a vertical rock section can be used to estimate palaeogeothermal gradients (e.g. Holford et al., 2005, 2009). Moreover, by extrapolation to an assumed palaeosurface temperature, the thickness of section removed during exhumation can be quantified (Green et al., 2002; Holford et al., 2005). Full methodological descriptions of the analytical and interpretative procedures by which thermal history data are extracted from apatite and vitrinite samples are provided by Green et al. (2001, 2002).

\subsection{Temperature history reconstruction using QTQt of well Hesketh-1}

Many recent attempts to model time-temperature histories of rocks from thermochronologic data have taken advantage of one of two, freely available software packages: HeFTy (Ketcham et al., 2015) and QTQt (Gallagher, 2012).

Employing a Bayesian transdimensional Markov chain Monte Carlo (MCMC) inversion scheme, QTQt constrains a set of best-fit temperature-time paths given a posterior probability distribution (Gallagher, 2012). Essential input parameters for models using this program are: the number of fission tracks per unit volume $\left(N_{s}\right)$, the number of induced tracks per unit volume $\left(N_{i}\right)$, composition (given as wt. \% Cl), track lengths (in microns), C-axis angle, calibration factor used in the External Detector Method $(\zeta)$, number of tracks 


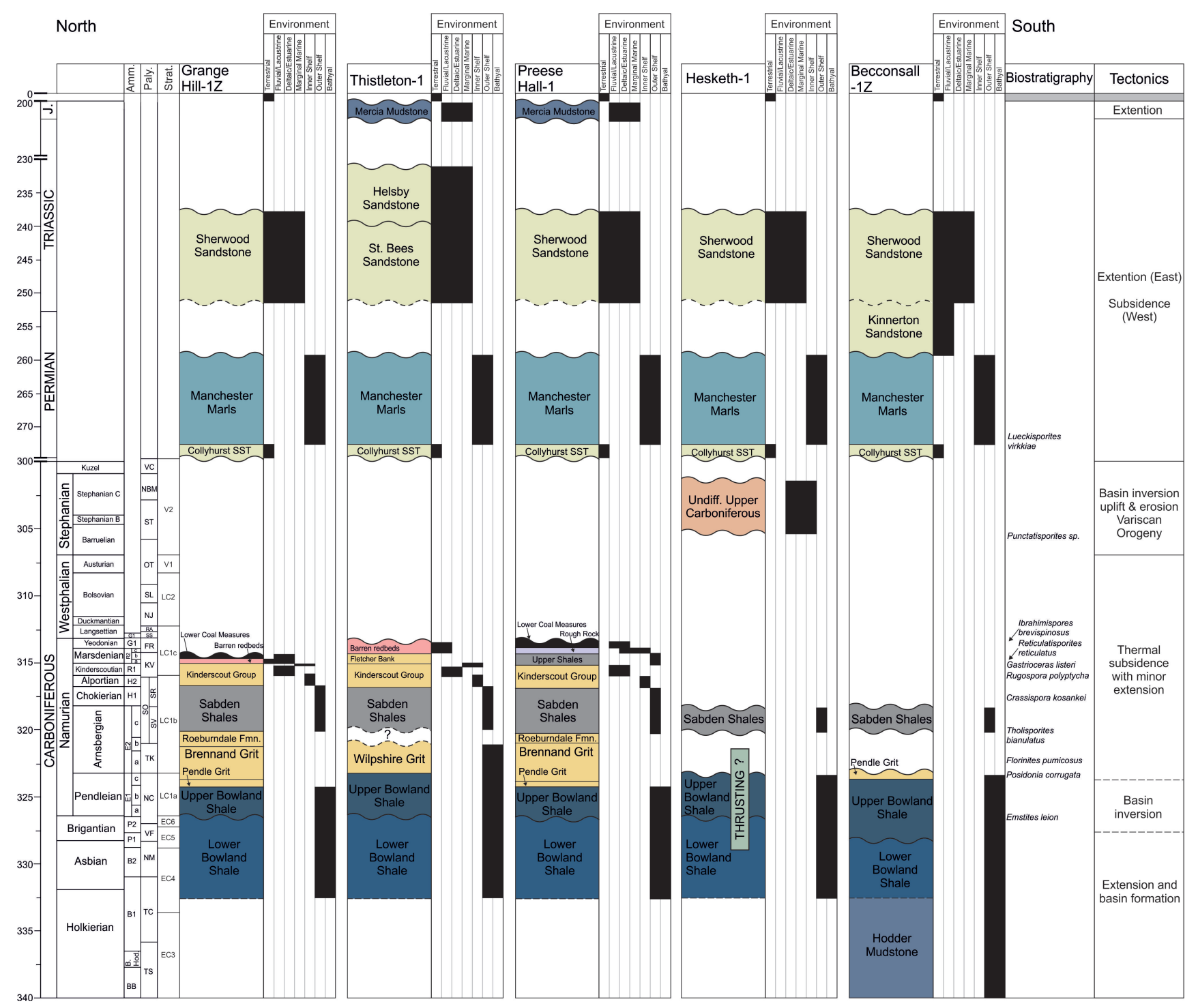

Figure 2: Biostratigraphy, paleo water depths and tectonic histories of wells used in this study. Biostratigraphy data are sourced from well completion reports. Stratigraphy and tectonic history after Fraser and Gawthorpe, 1990. 
counted in the dosimeter $\left(N_{d}\right)$, induced track density $\left(\rho_{D}\right)$, present day temperature $\left(T_{p}\right)$, depth $(Z)$ and geographic coordinates (X and Y from British National Grid, BNG, coordinates). Primary QTQt-model outputs include three time-temperature models:

- The maximum likelihood (ML) model is the model that fits the measured data the best but is the most complex.

- The maximum posterior (MP) model is the simplest model, where the posterior probability is proportional to the likelihood multiplied by the prior (no uncertainties are associated with the MP or the ML models).

- The expected (EX) model is essentially a weighted-mean model of intermediate complexity between the ML and MP models, where the weighting is provided by the posterior probability of each model solution. The iterative MCMC sampling can be used to calculate the uncertainty for the EX model and define the $95 \%$ credible interval (CI; Bayesian equivalent to the confidence interval) around the EX-model solution.

The QTQt software allows resampling of thermochronometric ages, commonly by assuming a normal distribution (the standard deviation) centred on the measured radiometric age $\left(N_{s} / N_{i}\right.$ ratio), or alternatively, resampling of the chosen kinetic parameter (i.e., measured $\mathrm{Cl}$ value), which is a way of recognising uncertainty in laboratory-calibrated kinetic models extrapolated to geological time scales (McDannell et al., 2021).

Apatite fission track data were obtained from two samples, GC402-17 and GC402-18, within the Triassic Sherwood Sandstone at well Hesketh-1 (Figure 1) at depths of $145 \mathrm{~m}$ and $521 \mathrm{~m}$, respectively. The original data were obtained by Geotrack Intl. and recently reprocessed to include compositional and C-axis angle information (Tables 1 - 4).

Bayesian transdimensional MCMC inversion modelling results obtained using QTQt (Gallagher, 2012) from well Hesketh-1 are shown on Figure 3. Results for the deeper sample, GC402-18, indicate a greater degree of cooling between $80-50 \mathrm{Ma}$ with a maximum Late Cretaceous paleotemperature of $90-100^{\circ} \mathrm{C}$. Results for the shallower sample, GC402-17, indicate maximum Late Creatceous paleotemperatures of $80^{\circ} \mathrm{C}$. The expected, max. likelihood and max. posterior models for both samples show cooling from maximum Late Cretaceous paleotemperatures of $90-100^{\circ} \mathrm{C}$ from $110-75 \mathrm{Ma}$ to present. 


\begin{tabular}{|c|c|c|c|c|}
\hline \multicolumn{5}{|c|}{ GC402-17 } \\
\hline Grain ID & $N_{s}$ & $N_{i}$ & Composition [wt.\% Cl] & FT age [Ma] \\
\hline 1 & 44 & 73 & 0.26 & $156.25 \pm 30.0$ \\
2 & 9 & 17 & 0.045 & $137.44 \pm 56.7$ \\
3 & 1 & 2 & 0 & $129.88 \pm 159.1$ \\
4 & 12 & 42 & 0.007 & $74.54 \pm 24.5$ \\
5 & 98 & 96 & 0.761 & $262.46 \pm 38.1$ \\
7 & 43 & 72 & 0.041 & $154.84 \pm 30.0$ \\
8 & 27 & 44 & 0.54 & $159.04 \pm 39.0$ \\
9 & 7 & 14 & 0 & $129.89 \pm 60.2$ \\
10 & 25 & 54 & 0 & $120.36 \pm 29.2$ \\
11 & 19 & 29 & 0.034 & $169.67 \pm 50.2$ \\
12 & 16 & 57 & 0.008 & $73.24 \pm 20.8$ \\
13 & 21 & 53 & 0.091 & $103.14 \pm 26.7$ \\
14 & 23 & 53 & 0.022 & $112.88 \pm 28.2$ \\
15 & 14 & 56 & 0.022 & $65.27 \pm 19.6$ \\
17 & 25 & 67 & 0.045 & $97.18 \pm 22.9$ \\
18 & 48 & 166 & 0 & $75.43 \pm 12.5$ \\
19 & 37 & 51 & 0.561 & $187.62 \pm 40.7$ \\
20 & 4 & 13 & 0.016 & $80.24 \pm 45.9$ \\
22 & 29 & 34 & 0.362 & $220.02 \pm 55.8$ \\
\hline
\end{tabular}

Table 1: AFTA data for Sample GC402-17 (1 of 4) from well Hesketh-1. Sample location X $=343001, \mathrm{Y}=425197$ (BNG coordinates), $Z=145 \mathrm{~m}$ and stratigraphic unit $=$ Sherwood Sandstone (Triassic). Modelling parameters: $\zeta=360.3, \rho_{D}=1.46 \times 10^{6}, N_{d}=2283$. Central age $=127.84 \pm 13.1 \mathrm{Ma}$, pooled age $=132.28 \mathrm{Ma}$, Dispersion $=34.12 \%, \mathrm{P}\left(\chi^{2}\right)=0$, Mean track length $=12.93, \sigma=2.216$. 


\begin{tabular}{|c|c|c|c|c|}
\hline \multicolumn{5}{|c|}{ GC402-18 } \\
\hline Grain ID & $N_{s}$ & $N_{i}$ & Composition & FT age [Ma] \\
\hline 1 & 2 & 3 & 0 & $171.97 \pm 157.016$ \\
3 & 63 & 108 & 0.091 & $150.72 \pm 24.058$ \\
4 & 20 & 117 & 0.004 & $44.53 \pm 10.807$ \\
6 & 80 & 154 & 0.103 & $134.39 \pm 18.69$ \\
8 & 55 & 206 & 0.212 & $69.42 \pm 10.616$ \\
9 & 51 & 182 & 0 & $72.84 \pm 11.62$ \\
10 & 26 & 75 & 0.134 & $90.00 \pm 20.55$ \\
12 & 16 & 54 & 0.115 & $77.00 \pm 21.963$ \\
13 & 27 & 48 & 0.055 & $145.40 \pm 35.082$ \\
14 & 52 & 169 & 0.076 & $79.94 \pm 12.764$ \\
15 & 15 & 50 & 0 & $77.95 \pm 22.995$ \\
16 & 27 & 88 & 0 & $79.71 \pm 17.6$ \\
17 & 15 & 45 & 0 & $86.56 \pm 25.857$ \\
18 & 59 & 114 & 0.016 & $133.90 \pm 21.618$ \\
19 & 14 & 36 & 0.039 & $100.87 \pm 31.827$ \\
20 & 12 & 12 & 1.373 & $256.26 \pm 104.727$ \\
21 & 12 & 52 & 0 & $60.05 \pm 19.263$ \\
23 & 26 & 89 & 0.056 & $75.92 \pm 16.984$ \\
24 & 9 & 14 & 0 & $165.90 \pm 70.949$ \\
\hline
\end{tabular}

Table 2: AFTA data for Sample GC402-18 (2 of 4) from well Hesketh-1. Sample location X $=343001, \mathrm{Y}=425197$ (BNG coordinates), $Z=521 \mathrm{~m}$ and stratigraphic unit $=$ Sherwood Sandstone (Triassic). Modelling parameters: $\zeta=360.3, \rho_{D}=1.45 \times 10^{6}, N_{d}=2283$. Central age $=95.51 \pm 8.5 \mathrm{Ma}$, pooled age $=109.32 \mathrm{Ma}$, Dispersion $=28.18 \%, \mathrm{P}\left(\chi^{2}\right)=0$, Mean track length $=12.67, \sigma=2.921$. 


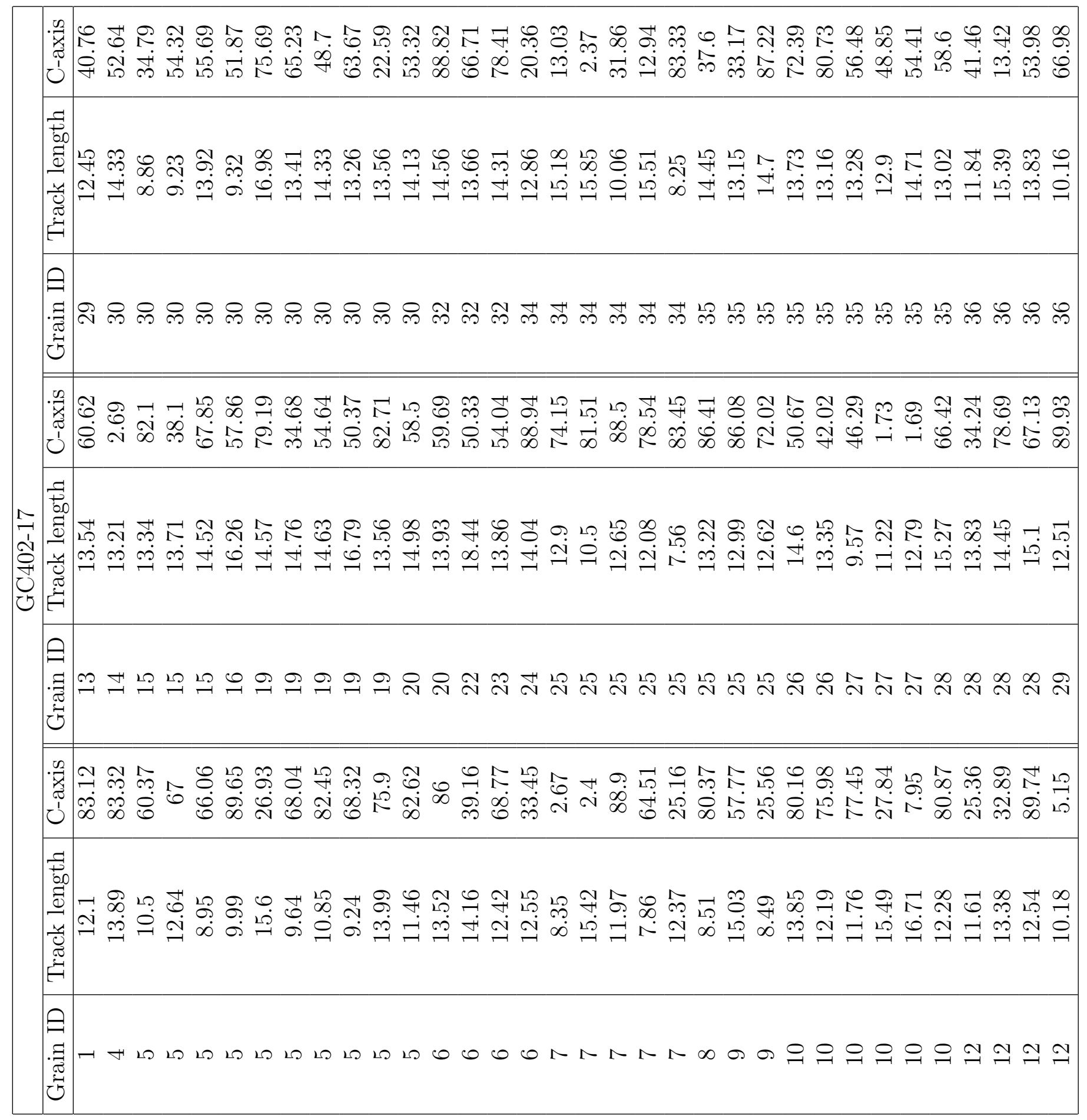




\begin{tabular}{|c|c|c|}
\hline & to & 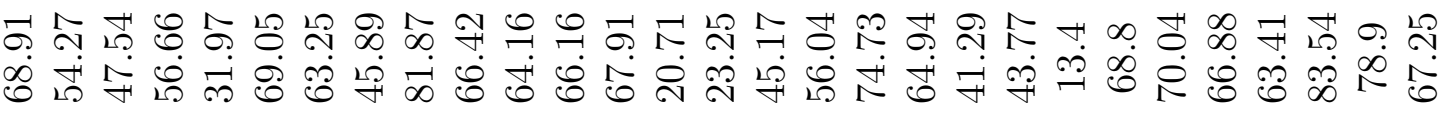 \\
\hline & 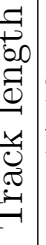 & 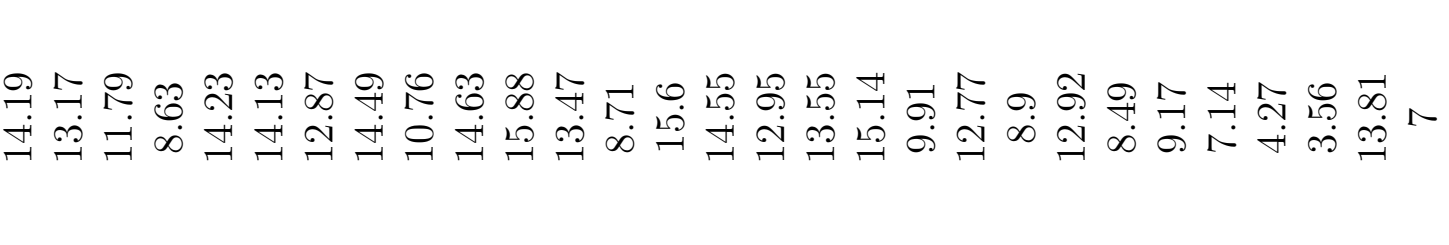 \\
\hline & 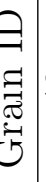 & 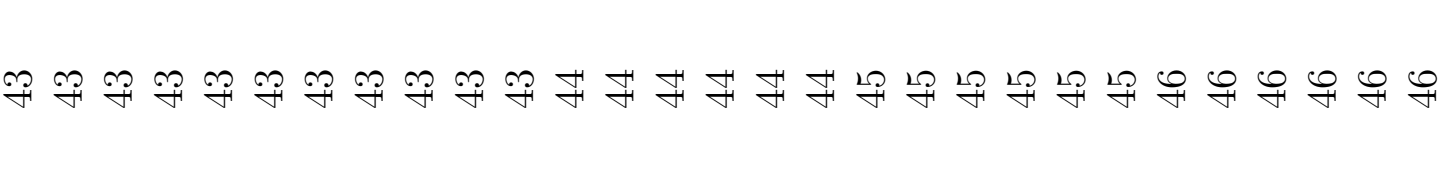 \\
\hline & 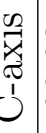 & 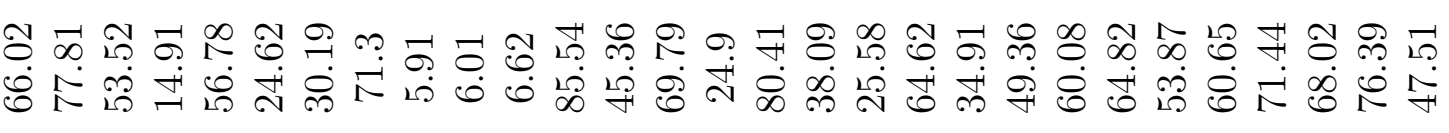 \\
\hline 我 & 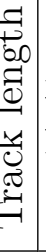 & 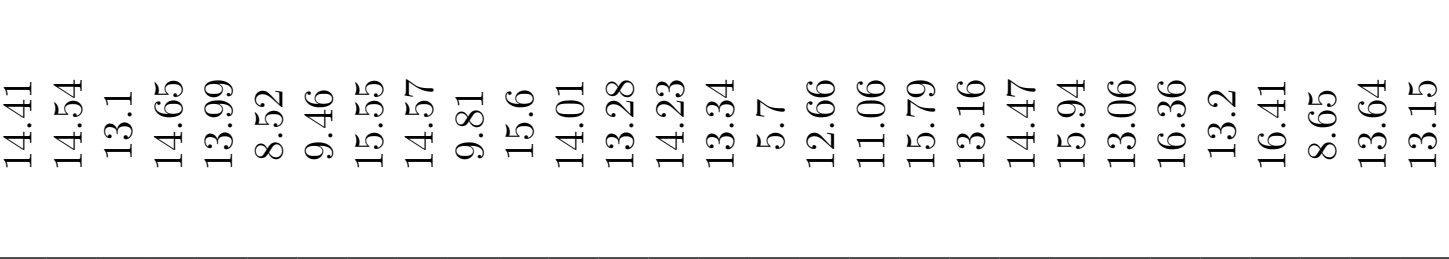 \\
\hline & 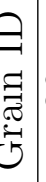 & 施 \\
\hline & | & 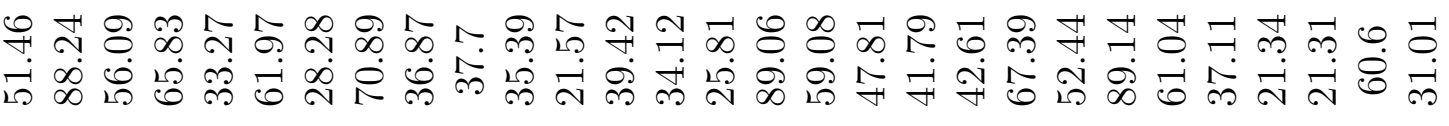 \\
\hline & 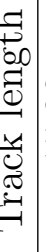 & 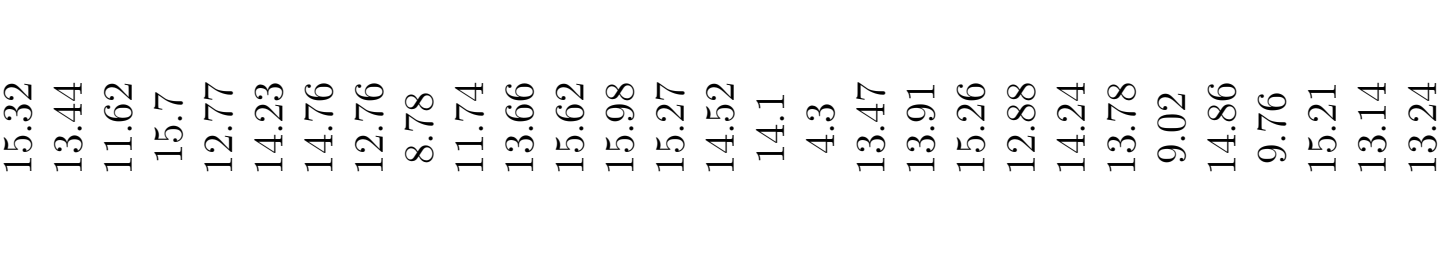 \\
\hline & 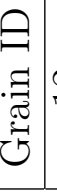 & 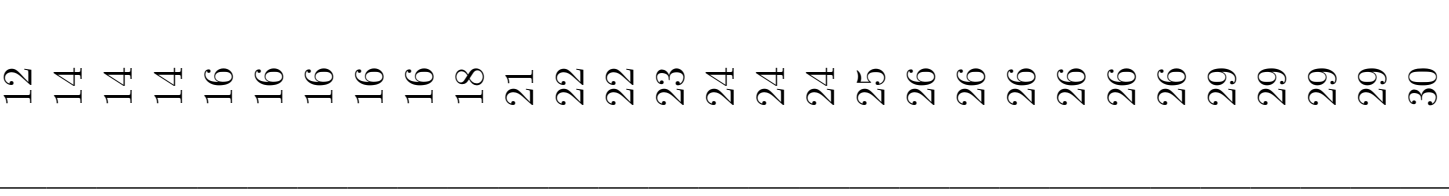 \\
\hline
\end{tabular}



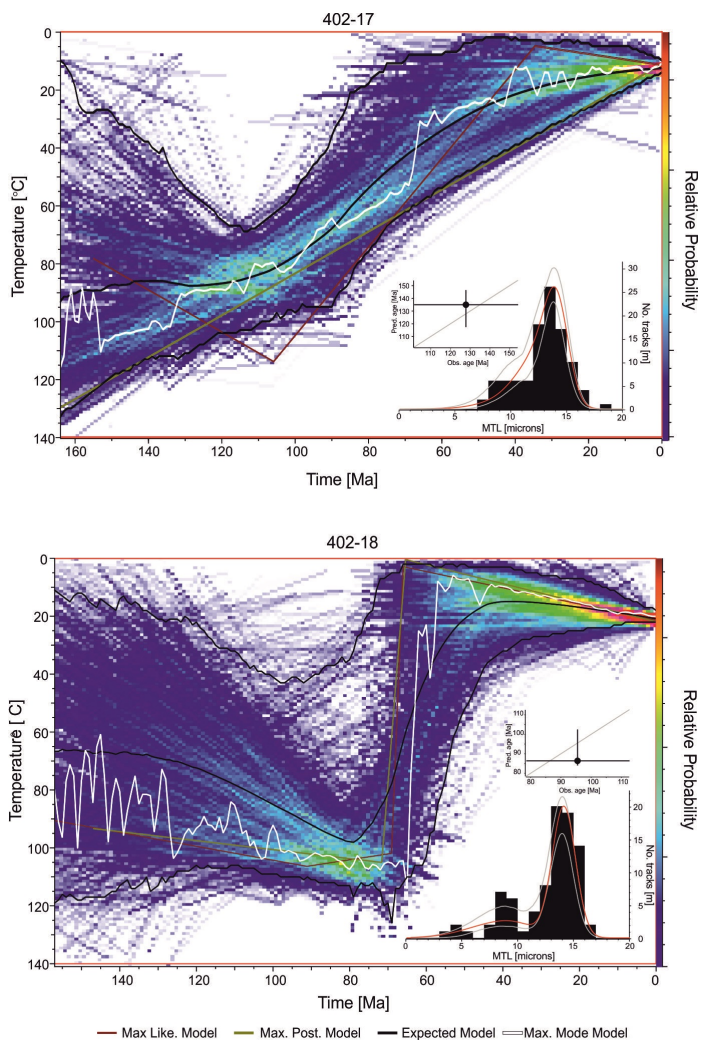

Figure 3: AFTA modelling results for Samples GC402-17 and GC402-18 from well Hesketh1. $\mathrm{MTL}=$ mean track length (microns). 


\subsection{Application to $1 D$ basin modelling}

Basin modelling is defined as the numerical simulation of basin development and geologic processes through geologic time (Hantschel and Kauerauf, 2009). It demonstrates the burial history of the sediments and combines geological information that includes formation thickness, age, porosity and lithology type to predict geological horizons.

The input parameters and thermal boundary conditions used in the assessment of wells in the Bowland Basin included:

- the paleowater depth (PWD, in metres), which was determined by examining paleomaps, specific facies, biostratigraphy and the time of deposition which allowed the approximation of sea levels in the study area (see Figure 2 for PWDs in each well). In accordance with the definition of depositional environments as described by Immenhauser (2009), the PWDs of the wells evaluated in this study ranged between terrestrial (present day) and bathyal $(>2000 \mathrm{~m})$.

- the synthesised sediment-water interface temperature (SWIT, in ${ }^{\circ} \mathrm{C}$ ), which normally varies over time was calculated using an inbuilt function Wygrala (1989). The model calculates appropriate temperatures over time after applying the study area's specific latitude and region. SWIT ranged from $5^{\circ} \mathrm{C}-25^{\circ} \mathrm{C}$ in the studied area.

- the paleo-heat flow (HF, in $\left.\mathrm{mW} / \mathrm{m}^{2}\right)$. A present day heat flow value of $55 \mathrm{~mW} / \mathrm{m}^{2}$ is also used (Downing and Gray, 1986) for the region.

Due to a lack of geological data owing to uplift and erosion over the last $200 \mathrm{Ma}$ and based on AFTA results from well Hesketh-1 in this study, a constraint of Late Cretaceous paleotemperatures of $90-100^{\circ} \mathrm{C}$ within the Sherwood Sandstone is applied to wells Grange Hill-1Z, Preese Hall1 and Thistleton-1 (Figure 5). Post-Jurassic deposition, erosion and Late Cretaceous-Present heat flow were varied to produce maturity profiles that correspond with measured vitrinite reflectance data (where available).

Regional stratigraphic (thickness) and vitrinite reflectance (palaeoburial) studies were used to estimate the degree of uplift and subsequent erosion of syn- and post-rift Carboniferous sediments in NW England. These studies highlight the extent to which basins such as Bowland and Northumberland, which are interpreted as lying normal to the NW-SE direction of maximum compressive stress, were inverted during the Variscan (Fraser and Gawthorpe, 


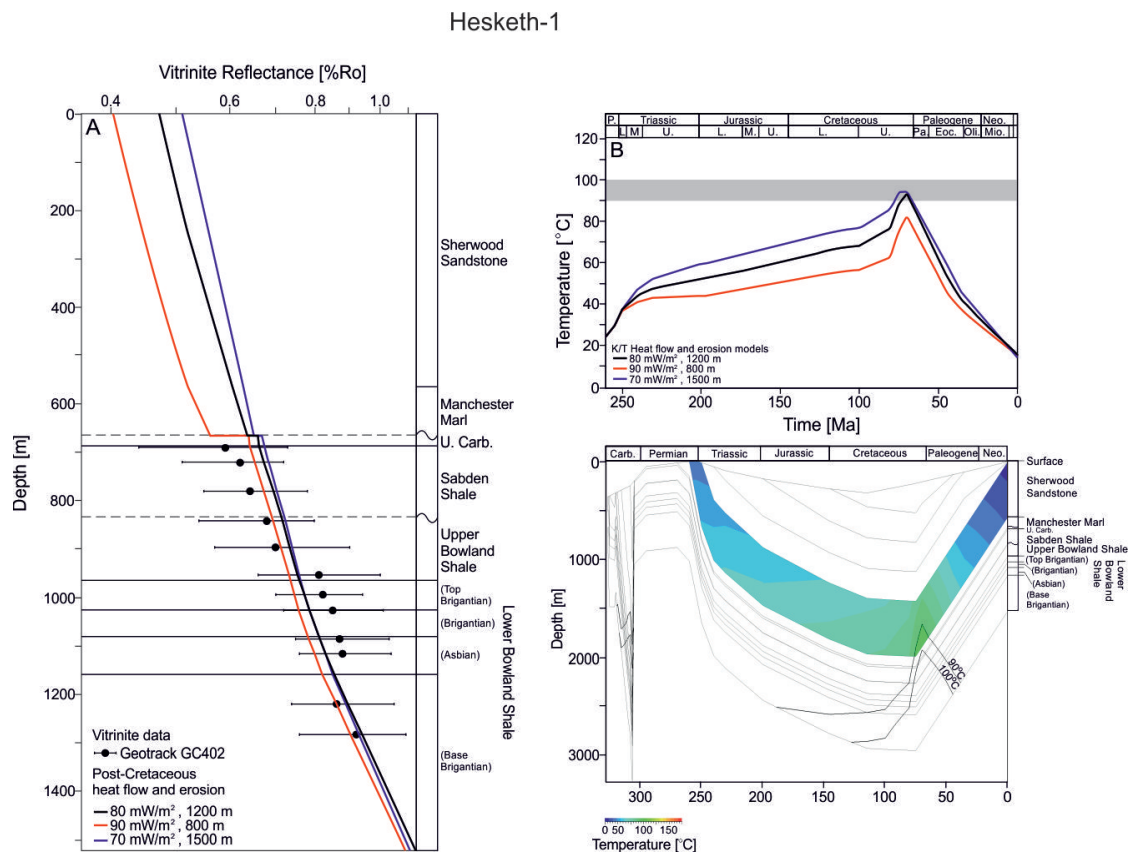

Figure 4: 1D basin modelling results for Hesketh-1. Thrust faulting within the Carboniferous section (Lower Bowland Shale) is accounted for in this model. A = maturity plot calculated using Carboniferous erosion $=2000 \mathrm{~m}$, Arnsbergian erosion $=100 \mathrm{~m}$ and postCretaceous erosion and heat-flow values as labelled. Dashed lines $=$ unconformities. $\mathrm{B}=$ temperature-time plot for Sherwood Sandstone. Results from AFTA (Figure 3) indicate that end Cretaceous/Paleogene paleotemperatures reached $90^{\circ} \mathrm{C}-100^{\circ} \mathrm{C} . \mathrm{C}=$ burial history plot with paleotemperature of Sherwood Sandstone. Black lines $=90^{\circ} \mathrm{C}-100^{\circ} \mathrm{C}$ isotherms. Paleo water depths (PWD) values from biostratigraphy as shown on Figure 2. Maturity data used to calibrate model from Green and Bray (1992).

1990). Estimates of Variscan erosion in the Bowland Basin range between 2000 in the north to $\sim 2500 \mathrm{~m}$ in the south. Hence, a value of $2300 \mathrm{~m}$ is used for well Hesketh-1 and $2000 \mathrm{~m}$ is used for wells Grange Hill-1Z, Preese Hall-1 and Thistleton-1 in the north of the basin. It is also important to note the absence of Namurian (Arnsbergian and Chokierian-Yoedonian) stratigraphy at Hesketh-1 (Figure 2). Based on the thickness of Namurian intervals encountered at other wells in the region, a value of $200 \mathrm{~m}$ is chosen for Namurian erosion at Hesketh-1.

1D basin modelling results for well Hesketh-1 calculated using maximum Late Cretaceous heat flow values $=70-90 \mathrm{~mW} / \mathrm{m}^{2}$ and erosion $=800-1500$ $\mathrm{m}$ all match maturity data (Figure 4). However, only heat flows of $70-80$ 
$\mathrm{mW} / \mathrm{m}^{2}$ and erosion of $1200-1500 \mathrm{~m}$ allow allow for Sherwood Sandstone to reach paleotemperature of $90-100^{\circ} \mathrm{C}$, with higher heat flow corresponding with lower erosion values. Furthermore, the large offset in vitrinite reflectance profile at the Variscan unconformity produced for heat flow $=90 \mathrm{~mW} / \mathrm{m}^{2}$ and erosion $=800 \mathrm{~m}$ at Hesketh -1 (red line in Figure $4 \mathrm{~A})$ is inconsistent with the small/miniscule offsets seen at all other wells analysed in this study.

Results for Grange Hill-1 $Z$ indicate maximum Late Cretaceous heat flow $=62 \mathrm{~mW} / \mathrm{m}^{2}$ and erosion $=1450 \mathrm{~m}$, as higher heat flow/lower erosion scenarios either do not match calibration data or do not produce adequate paleotemperature in the Sherwood Sandstone. Results for Preese-Hall-1 indicate maximum Late Cretaceous heat heat flow $=80-90 \mathrm{~mW} / \mathrm{m}^{2}$ and erosion $=700-850 \mathrm{~m}$. Results for Thistleton -1 indicate maximum Late Cretaceous heat flow $=62.5-65 \mathrm{~mW} / \mathrm{m}^{2}$ and erosion $=1000-1200 \mathrm{~m}$.

\section{Resource potential from regional $2 \mathrm{D}$ basin modelling}

Results from 1D basin modelling (Figures 4 and 5) indicate maximum Late Cretaceous heat flow and erosion of $62.5-65 \mathrm{~mW} / \mathrm{m}^{2}$ and $1000-1450$ $\mathrm{m}$, respectively at wells Grange Hill-1Z and Thistleton-1 in the north of the Bowland Basin and values of $70-80 \mathrm{~mW} / \mathrm{m}^{2}$ and $1200-1500 \mathrm{~m}$ in at well Hesketh-1 in the south. Figure 7 shows a N-S oriented regional composite seismic line crosses the majority of the Bowland Basin, produced using the $100 \mathrm{~km}^{2}$ Bowland-12 3D seismic survey and data provided by Beneath Britain, University of Oxford, UK. This line intersects well Thistleton-1 in the north and Hesketh-1 in the south. The position of well Grange-Hill-1Z is projected onto Figure 7, however the well is located $<1 \mathrm{~km}$ away from the seismic profile. Data from the Bowland-12 3D seismic survey (shot by Cuadrilla, 2012) and 2D seismic lines GC82 - 343 (shot by Horizon, 1982), GCE-86 - 360 (shot by Horizon, 1986)and UKOGL-RG-006 are combined to generate a regional composite line that intersects Thistleton-1 and Hesketh-1 and extends N-S across the Bowland Basin (Figure 7). Checkshot data for Thistleton-1 and Hesketh-1 from the UK Onshore Geophysical Library (UKOGL) was used to constrain seismic velocities and depth convert seismic data.

\section{Sedimentary facies assignment}

The facies maps used to build the 2D model were generated by combining the existing regional facies interpretation (Fraser and Gawthorpe, 1990), 

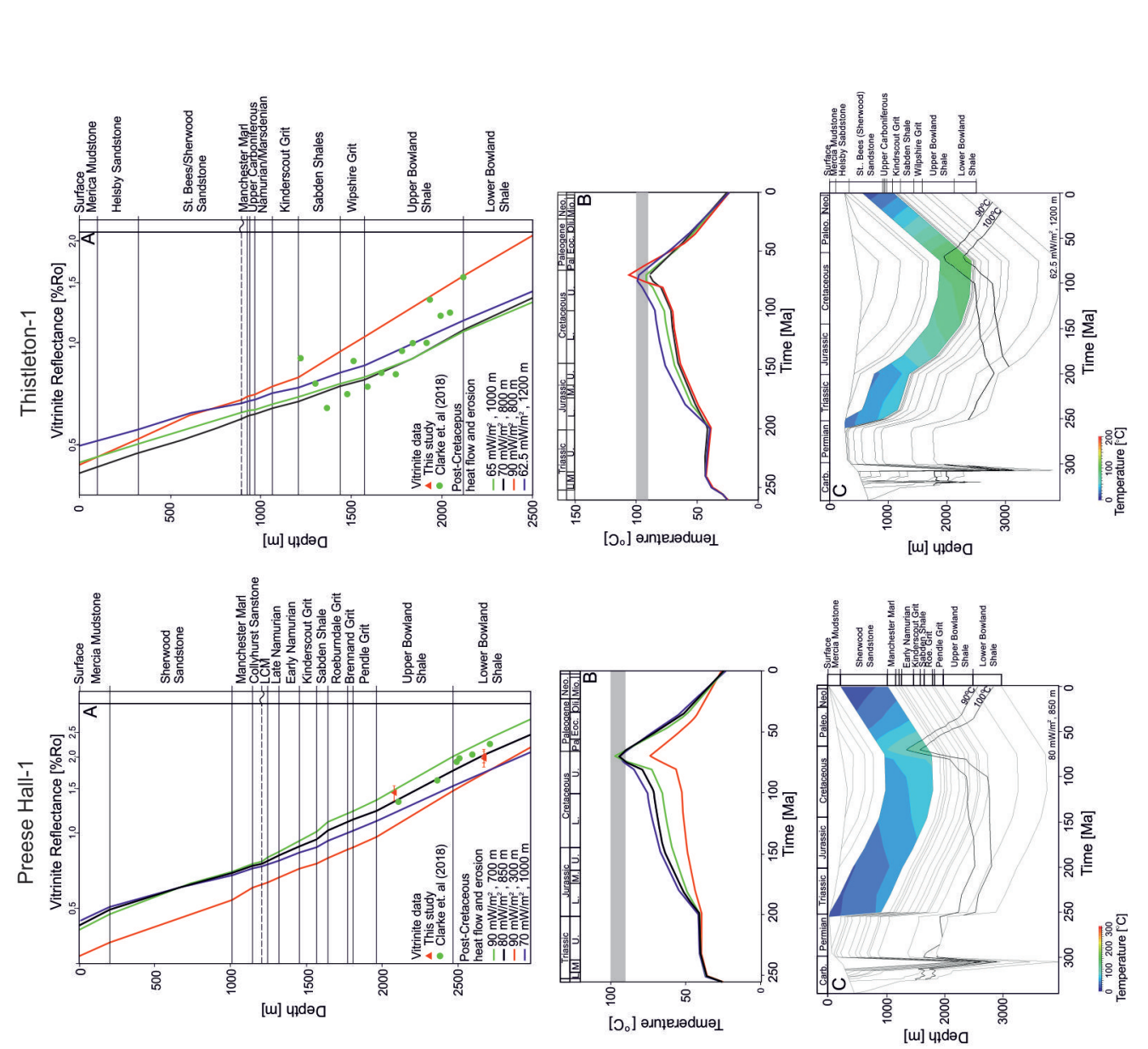

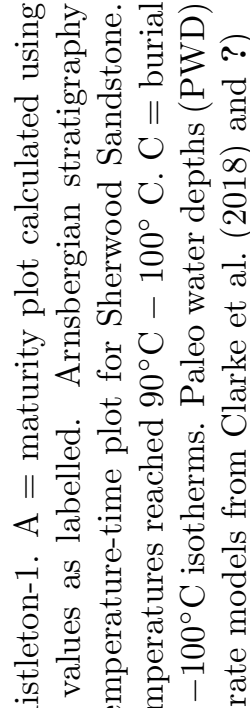
灵宁 - 11 造 8 .

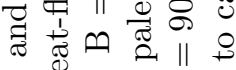

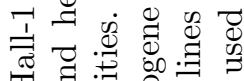
西 षै

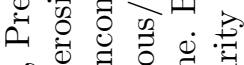

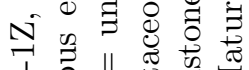

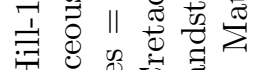
䨤寻

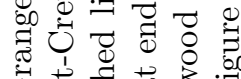
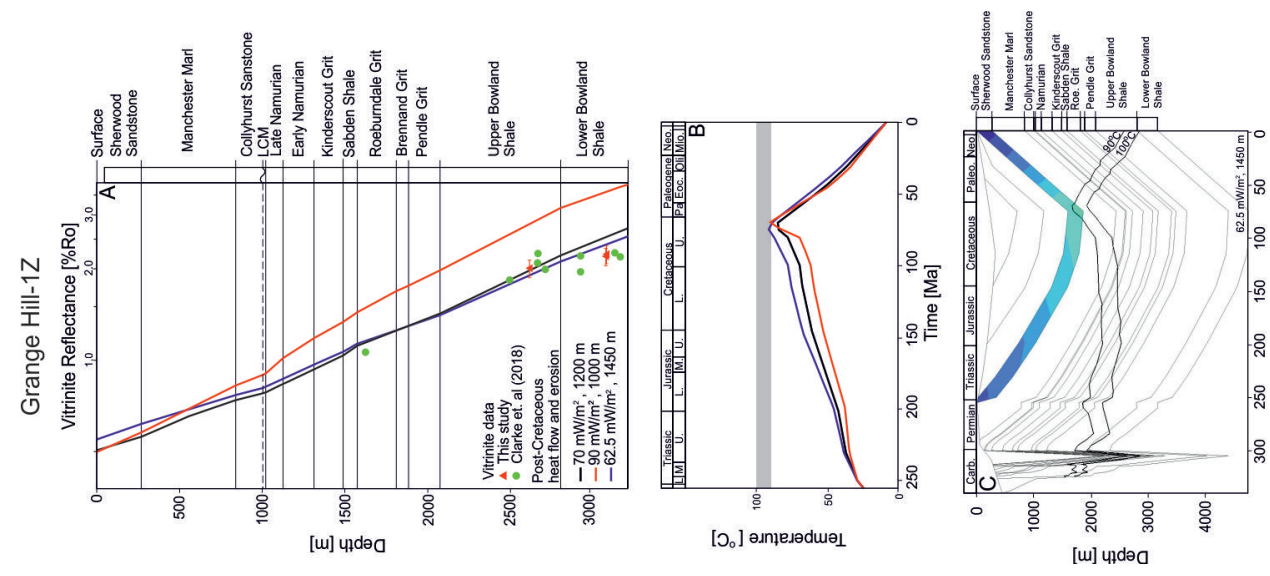

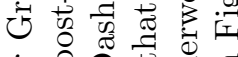

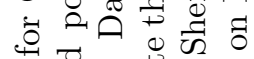

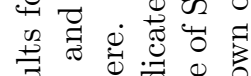
跑

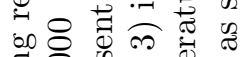

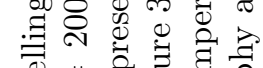

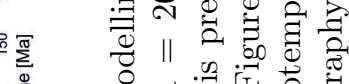

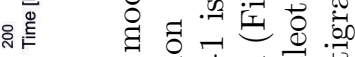

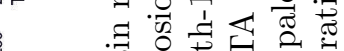

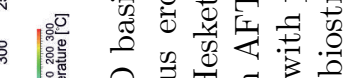

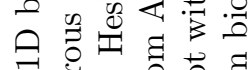

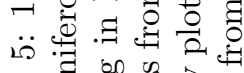

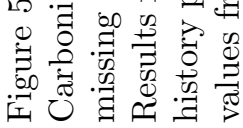


borehole data and seismic stratigraphy. Within the Bowland Basin, the Bowland Shale is interpreted to have been sourced by rivers delivering sediments from basement highs in the north. This contrasts with deposition of the Bowland Shale in sub-basins to the east, e.g. the eastern part of the Gainsborough Trough was influenced by distal clastic input sourced from the Fenno-Scandian landmass to the NE (Palci et al., 2020). Paleogeographic reconstructions from Fraser and Gawthorpe (1990) were used to infer the position of the shelf edge, basin centre and regions of increased clastic/carbonate influence during Early Carboniferous rifting (Figure 6). The proportion of clastic to non-clastic sediment is inferred to decrease towards the basin centre. Shale:clastic ratios for Lower and Upper Bowland Shales are inferred as 2:1 and 4:1 in the centre of the basin and 1:1 and 2:1 at the edges of the basin, respectively. Increased clastic influence in the northern Bowland Basin is reflected by the inclusion of mixed sand/shale Sabden Shale sedimentary facies and post-Carboniferous facies are assumed continuous across the basin.

\section{Source rock properties and kinetics}

Several important source rock properties must be considered to evaluate hydrocarbon generation during basin modelling. These include the total organic carbon $\left(\mathrm{TOC}_{0}\right)$, the initial hydrogen index $\left(\mathrm{HI}_{0}\right)$ and first-order kinetic reactions (i.e. the activation energies and frequency factors) . Whilst the Bowland Shale is characterised by a vertical lithological variation which reflects both minor and major cycles of sea-level change and variations in carbonate and clastic input, analysis conducted on core in the Bowland Basin and Widmerpool Gulf suggests that the Bowland Shale yields a high and consistent TOC concentration (Gross et al., 2015; Clarke et al., 2018; Palci et al., 2020). Hence for simplicity, $\mathrm{TOC}_{0}$ has been modelled as vertically homogeneous within the Bowland Shale (Palci et al., 2020).

$\mathrm{TOC}_{0} \mathrm{HI}_{0}$ values applied in $2 \mathrm{D}$ modelling in this study were estimated by back-calculating present-day TOC and HI measurements from well and Rock Eval (C) pyrolysis data at Thistleton-1 and Hesketh-1. Average $\mathrm{TOC}_{0}$ values for the Upper and Lower Bowland Shale are as follows: 2.71\% and 1.3\% at Thistleton-1 and $3.56 \%$ and $2.59 \%$ at Hesketh-1. Average $\mathrm{HI}_{0}$ values for the Upper and Lower Bowland Shale are as follows: $600 \mathrm{mgHC} / \mathrm{gTOC}$ and $300 \mathrm{mgHC} / \mathrm{gTOC}$ at Thistleton -1 and $600 \mathrm{mgHC} / \mathrm{gTOC}$ and $343 \mathrm{mgHC} / \mathrm{gTOC}$ at Hesketh-1. For 2D basin modelling, average $\mathrm{TOC}_{0}$ values of $2.01 \%$ and $2.59 \%$ were applied for the Upper and Lower Bowland Shales, respectively. 


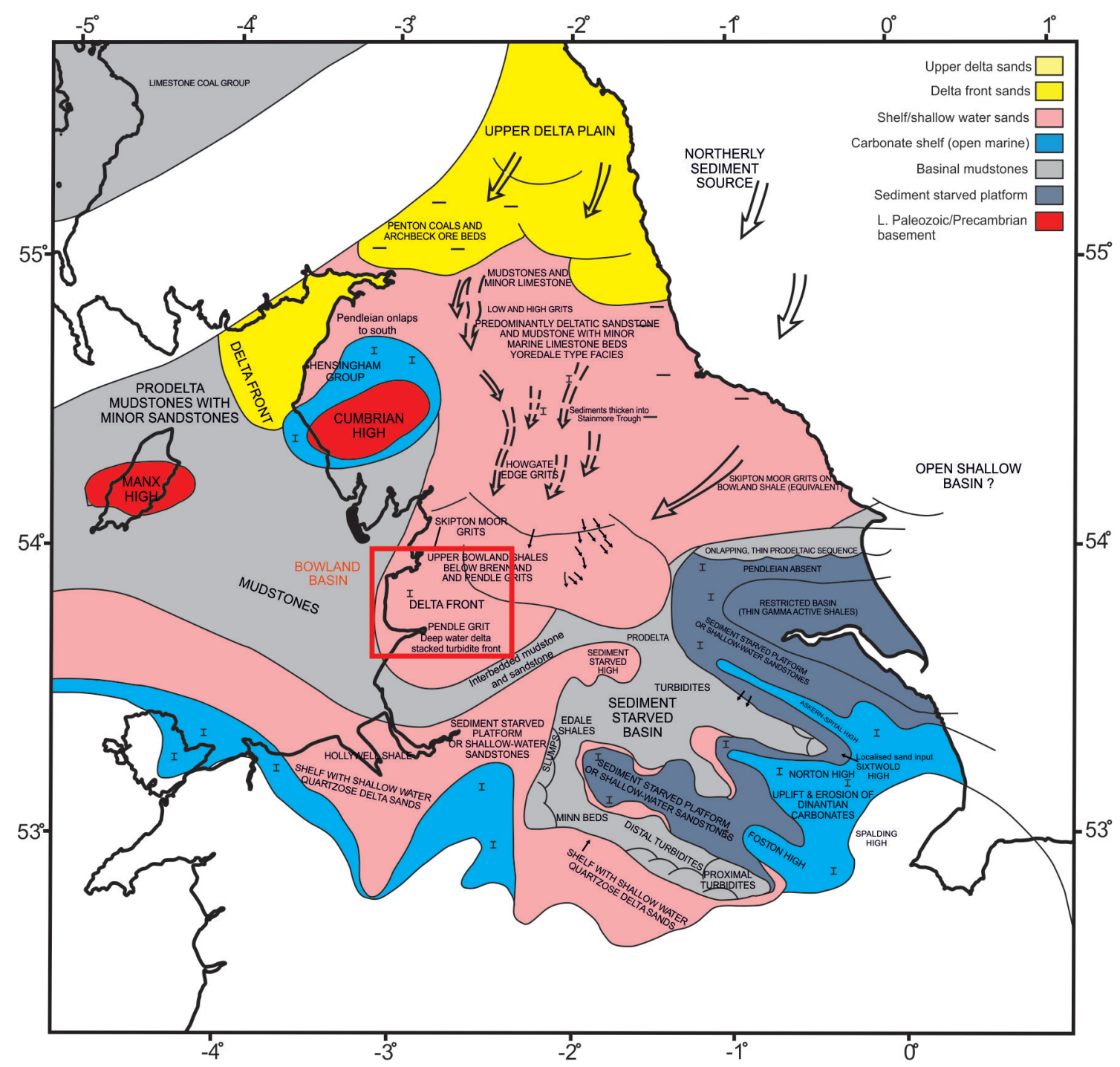

Figure 6: Regional Brigantian - Early Pendlein paleogepgraphy across Northern England. Note the different clastic sources for each sedimentary basin. Adapted from Fraser and Gawthorpe (2003). Red box = Bowland Basin. 
Average $\mathrm{HI}_{0}$ values of $450 \mathrm{mgHC} / \mathrm{gTOC}$ and $471 \mathrm{mgHC} / \mathrm{gTOC}$ were applied for the Upper and Lower Bowland Shales, respectively. TOC values are varied by $\pm 50 \%$ to create low, medium and high modelling scenarios that reflect the variability of the Upper and Lower Bowland shale across the basin.

To predict composition, masses and phases of hydrocarbons expelled from the Bowland Shale, a 14-component kinetic reaction (compositional phase kinetic) must be applied. The 14-component scheme is suitable for predicting phase properties such as the gas/oil ratio (GOR), API gravity and saturation pressure (Hantschel and Kauerauf, 2009). Yang et al. (2015) analysed samples of Bowland Shale that contained immature, marine Type II kerogen. Whilst this composition is generally typical for the Bowland Shale across Northern England, the analyses of Yang et al. (2015) contained compositional differences between the whole rock and kerogen. Whole rock samples are characterised by low HI and Type III organic matter, whereas the kerogen shows high HI and Type II organic matter. Hence, the kinetic reaction of Yang et al. (2015) may not be representative of the Bowland Shale in the Bowland Basin, where both Type II and III kerogen are observed. Palci et al. (2020) increased and decreased the primary and secondary cracking activation energy of the kinetic reaction of Yang et al. (2015) by $3 \mathrm{kcal} \mathrm{mol}^{-1}$ to model the high- and low-case scenarios for the Gainsborough Trough, respectively. Palci et al. (2020)'s sensitivity analyses shows that the kinetic reaction plays a critical role in the generated and expelled hydrocarbons and hydrocarbon component distribution. Palci et al. (2020)'s adaptation of the kinetic reaction of Yang et al. (2015) is applied to the 2D modelling within the Bowland Basin.

\section{Thermal boundary conditions}

Results from 1D basin modelling at Thistleton-1 and Hesketh-1 are applied to constrain paleo heat flow and estimates for erosion. A value for maximum heat flow during Early Cretaceous rifting of $65 \pm 5 \mathrm{~mW} / \mathrm{m}^{2}$ is assumed (Allen and Allen, 2005). Late Cretaceous paleo heat flows of $62.5 \mathrm{~mW} / \mathrm{m}^{2}$ and $70 \mathrm{~mW} / \mathrm{m}^{2}$ at Thistleton -1 and Hesketh -1 , respectively. Results of AFTA analysis indicate peak paleotemperatures of $90-100^{\circ} \mathrm{C}$ were reached in the Sherwood Sandstone at $70-80$ Ma. For the purposes of $2 \mathrm{D}$ basin modelling, these results are interpreted to indicate the onset of erosion of at the Base Maastrictian (72.1 Ma). Values for Late Cretaceous - Recent erosion of $1200 \mathrm{~m}$ and $1500 \mathrm{~m}$ are applied at Thistleton -1 and Hesketh -1 , respectively. Values for paleo heat flow and Late Cretaceous - Recent erosion fit within 
the ranges indicated by $1 \mathrm{D}$ modelling at individual wells. Biostratigraohic data (Figure 2) are used to calculate paleowater depths and seawater interface temperatures (SWIT) are calculated using Wygrala (1989)'s method for a latitude of $53^{\circ}$.

\section{Shale gas resource estimate}

The total volumes of in-place hydrocarbons in the Lower Bowland Shale are $0.15,0.29$ and $0.42 \mathrm{TCF}$ for the low, medium and high case scenarios, respectively. The total volumes of in-place hydrocarbons in the Upper Bowland Shale are 0.17, 0.33 and 0.48 for the low, medium and high case scenarios, respectively. The total volumes of in-place hydrocarbons accumulated in both the Upper and Lower Bowland Shale are 0.32, 0.62 and 0.90 TCF for low, medium and high case scenarios, respectively. Hydrocarbon accumulations in reservoirs are overwhelmingly dominated by hydrocarbon gases, with $\sim 35 \%$ methane, $\sim 13 \%$ ethane, $\sim 51 \%$ other gases (propane to n-pentane) and $\sim 1 \%$ hydrocarbon liquids. Hence, in-place hydrocarbon estimates correspond to gas in-place (GIP) estimates. 2D basin modelling results are summarised on Figure 8.

Our results indicate a combined GIP of 19.1, 37.1 and $53.7 \mathrm{BCF} / \mathrm{sq}$. mile for low, medium and high case scenarios, respectively, along the 2D section studied. These values are equivalent to $11.9,23.2$ and $33.6 \mathrm{BCF} / \mathrm{km}^{2}$ for the low, medium and high case scenarios, respectively. Using an approximate basin area of 3583 sq. miles, or $9281 \mathrm{~km}^{2}$ (see Figure 1 in Clarke et al., 2018), extrapolation of $2 \mathrm{D}$ basin modelling results gives a bulk shale gas resource potential of 68.5, 132.6 and 192.5 TCF for low, medium and high case scenarios, respectively. Applying an approximate recovery factor of $\sim 10 \%$ thus yields a total GIP of 6.9, 13.3 and 19.3 TCF within the Upper and Lower Bowland Basin. Assuming a recovery factor of $10 \%$, these values yield a total shale gas resource estimate of $\sim 13.1 \pm 6.4 \mathrm{TCF}$.

\section{Timing of hydrocarbon generation and conventional resource esti- mate}

The total volumes of hydrocarbons generated (bulk generation balance) in the Lower Bowland Shale are 3.56, 6.09 and 8.37 TCF (trillion cubic feet) for the low, medium and high case scenarios, respectively. The total volumes of hydrocarbons generated (bulk generation balance) in the Upper Bowland Shale are 1.19, 2.09 and 2.92 TCF for the low, medium and high 

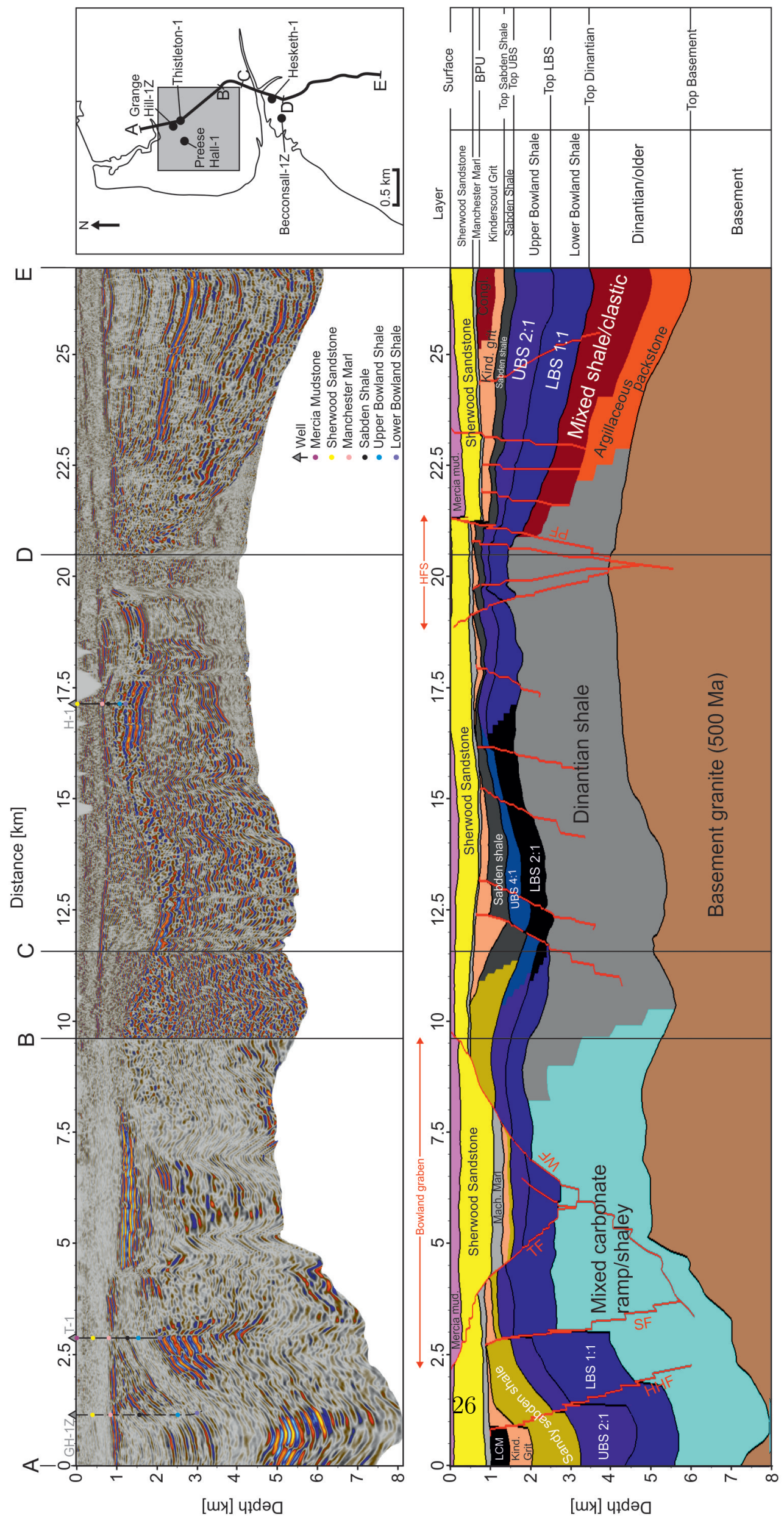

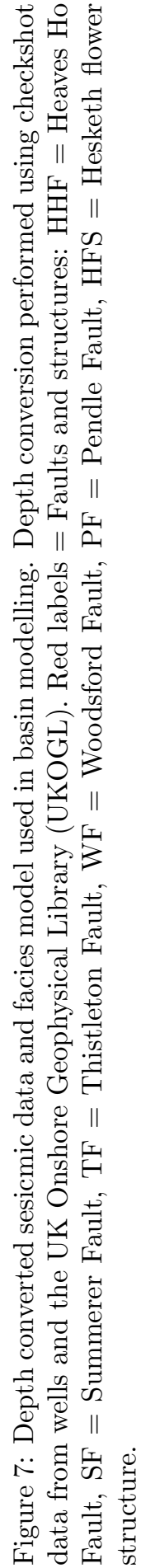


case scenarios, respectively. The total volumes of hydrocarbons accumulated in reservoirs are $0.22,0.26$ and $0.30 \mathrm{TCF}$ for low, medium and high case scenarios, respectively. Hydrocarbon accumulations in reservoirs are overwhelmingly dominated by hydrocarbon gases, with $\sim 35 \%$ methane, $\sim 13 \%$ ethane, $\sim 51 \%$ other gases (propane to n-pentane) and $\sim 1 \%$ hydrocarbon liquids. 2D basin modelling results are summarised on Figure 8.

\section{Discussion}

Generation, maximum burial and loss of resources during uplift

Our results indicate that hydrocarbon generation within the Lower Bowland Shale begins during the Brigantian north of the Summerer Fault where reach depths of $3-4 \mathrm{~km}$. Modest generation within the Lower Bowland Shale during late Arnsbergian times is also seen south of the Pendle Fault within a syncline that reaches depths of $2.5-3 \mathrm{~km}$. Hydrocarbon generation within the Upper Bowland Shale nort of the Summerer fault and south of the Pendle fault begins during the Westphalian where depths reach $3-4$ $\mathrm{km}$. Generation in both units continues throughout the Carboniferous, with increasing generation to the south of the basin. The transformation ratio (TR) of the Lower Bowland Shale reached $\sim 1$ across the majority of the study area by the Late Carboniferous below $2500 \mathrm{~m}$ depth, indicating that the majority of kerogen had transformed into hydrocarbons by this time. However, above $2500 \mathrm{~m}$ the TR of the Upper Bowland Shale is $<0.6$ around the Thistleton Fault, Woodsford Fault and Hesketh Flower Structure (Figure 9. Prior to the onset of Late Cabonferous - Permian erosion driven by the Variscan orogeny, the bases of the Upper and Lower Bowland shale reach maximum depths of $6.2 \mathrm{~km}$ and $5.3 \mathrm{~km}$ north of the Summerer Fault.

A further period of secondary generation within the Upper Bowland Shale is indicated up uo the point of maximum burial during the Late Cretaceous, whereby $\mathrm{TR}$ values reach $\sim 0.9-1$ within the Bowland graben and south of the Pendle Fault. During this period, the bases of the Upper and Lower Bowland Shale reach maximum depths of $6.8 \mathrm{~km}$ and $5.8 \mathrm{~km}$, respectively. Modest generation within the Lower Bowland Shale during this period is seen in a small region around the Bowland graben. The reason for the relatively high degree of hydrocarbon generation within the Upper Bowland Shale during this period is likely due to its shorter period of time within the generation window prior to Variscan erosion. Unlike the Upper Bowland Shale, the conditions required to place the Lower Bowland Shale within the 

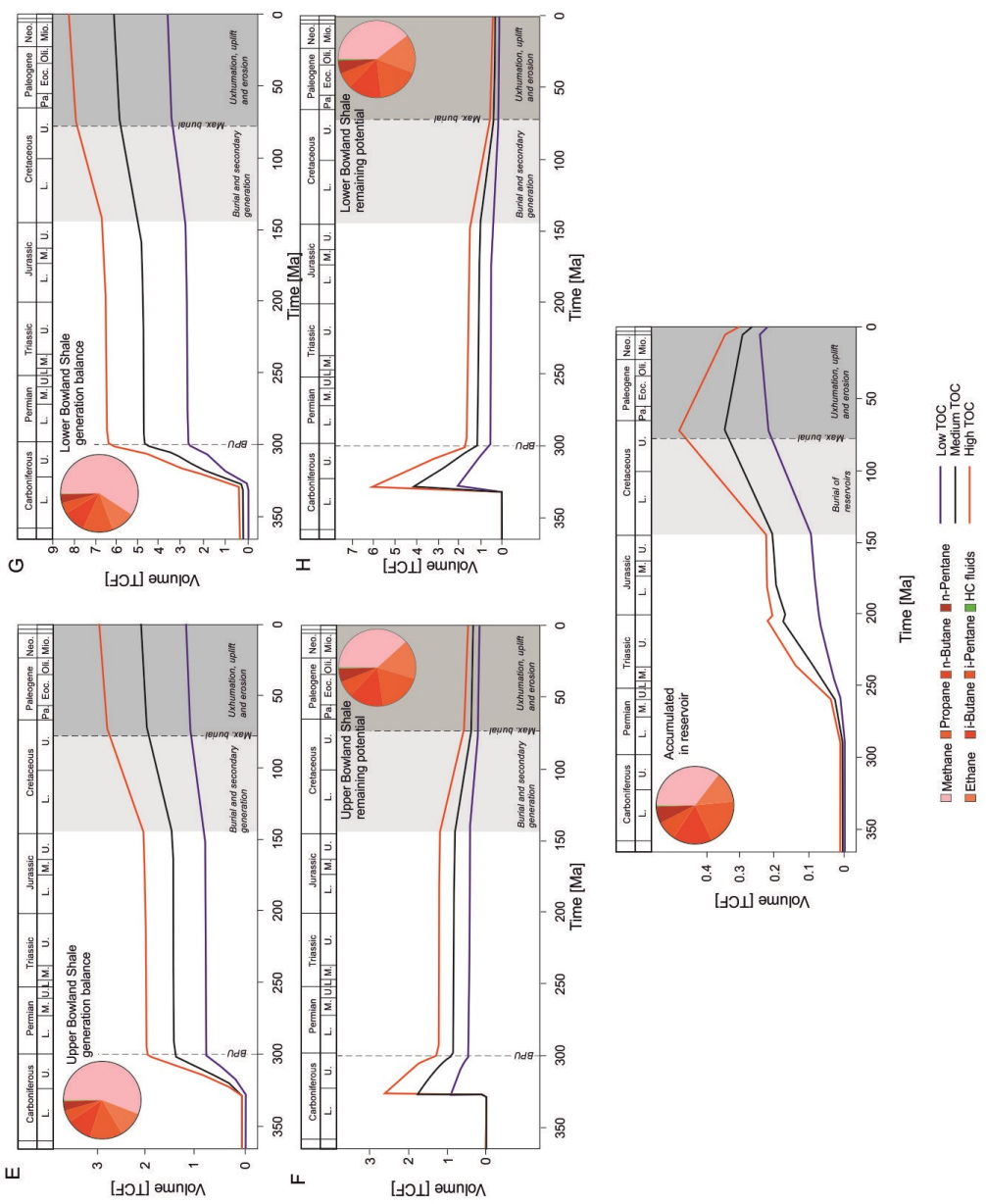

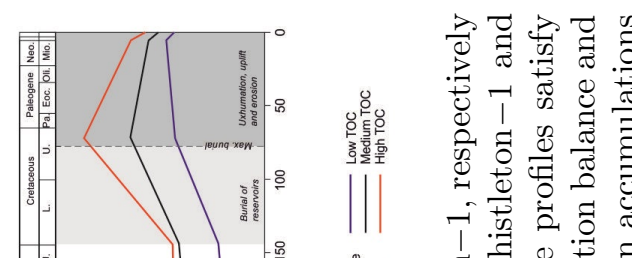

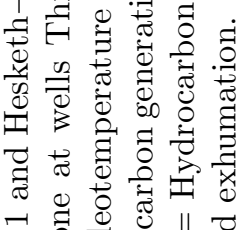

ᄀ古宓

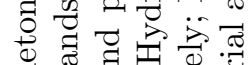

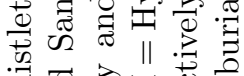

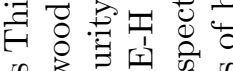

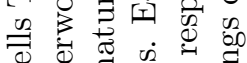

击

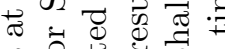

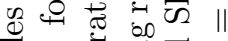

党, 品

20

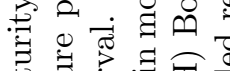

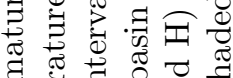
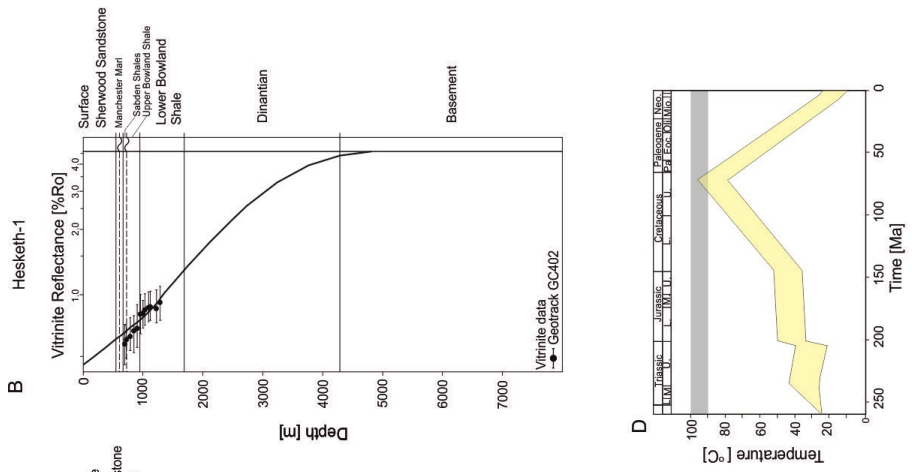

สี

द्व

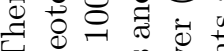

II

๑ $\|$ \&

ซี

«

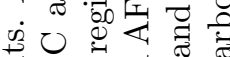

离
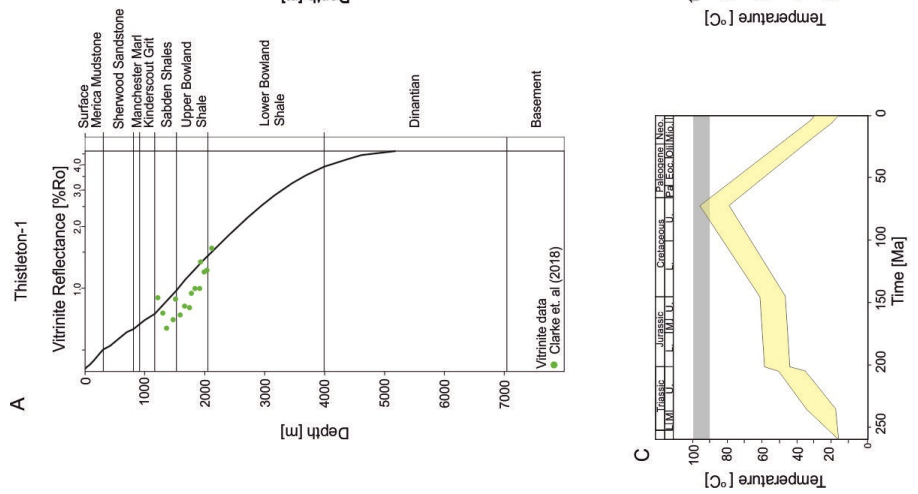

o.

ॠ

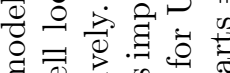

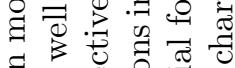

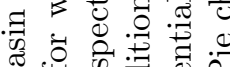

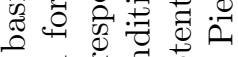

ลิ

$\ddot{\infty} \exists$ ।

讷苛寻寻

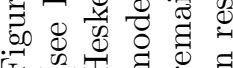



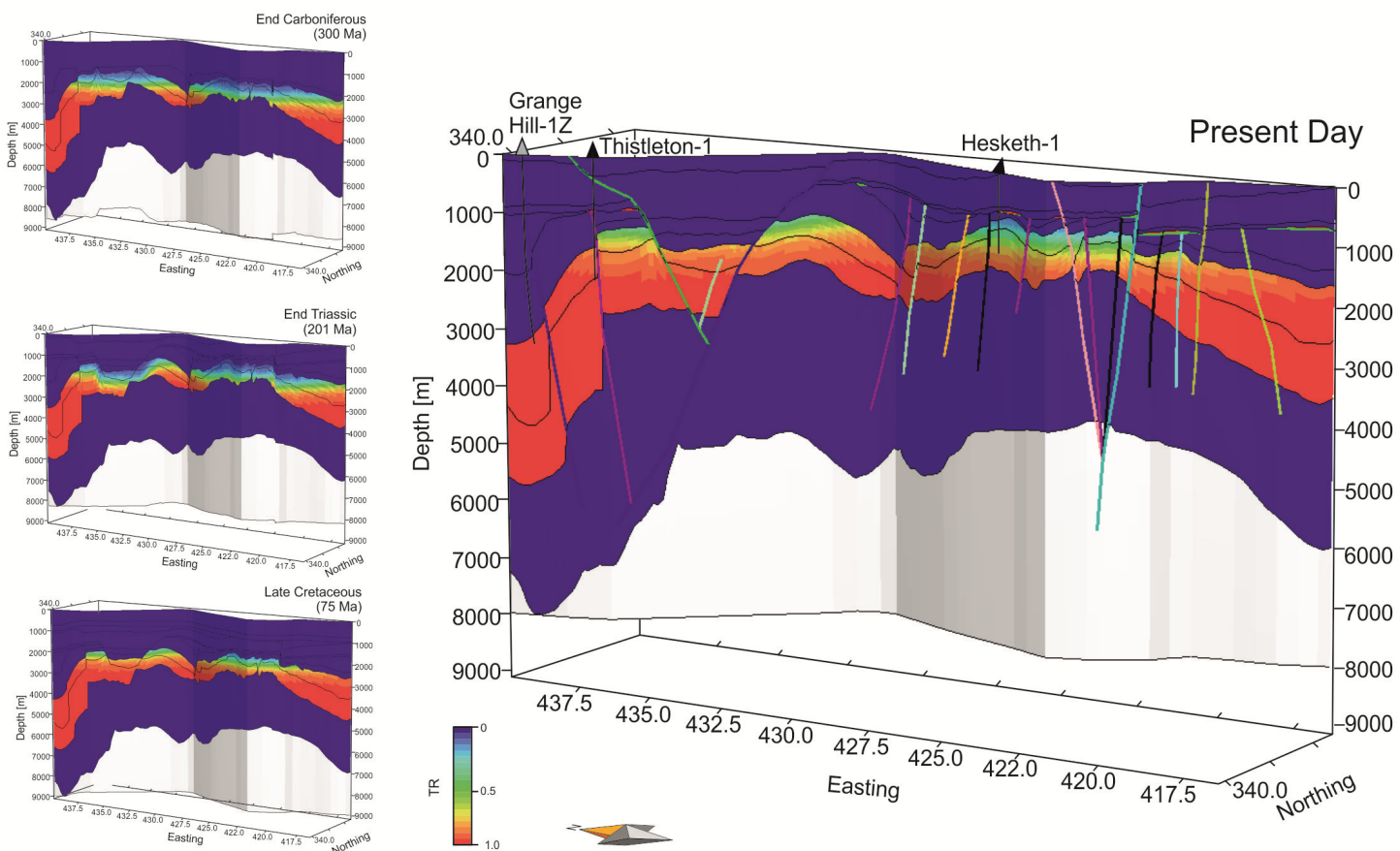

Figure 9: Calculated transformation ratios (TR) within the Upper and Lower Bowland Shale at End Carboniferous, End Triassic, Late Cretaceous and Present times. Non-source rocks have $\mathrm{TR}=0$. Present day faults are shown by coloured lines. Triangles $=$ position of wells; black $=$ intersected, grey $=$ projected. Location of modelled section shown on Figure 1. 
oil and gas window existed for $\sim 25 \mathrm{Ma}$ from Mid- to Late Carboniferous times. During this period, the Lower Bowland Shale is likely to have generated and expelled most of its hydrocarbons whilst the Upper Bowland Shale remained relatively under mature. The point of maximum burial is followed by the onset of exhumation, uplift and erosion of Cretaceous-Triassic strata across the basin. AFTA analyses and 1D basin modelling results in this study allow for consideration of the impact of burial during the Cretaceous on hydrocarbon generation, and provides a geological hypothesis for the loss of in-place hydrocarbons in the Bowland Shale.

Our results indicate a resource potential significantly lower than that of previous works, e.g. (Andrews, 2013) and are remarkably close to recent estimates obtained by high pressure water pyrolysis experiments (Whitelaw et al., 2019). Whilst the extrapolation of 2D basin modelling results applied in this study represents a significant simplification, our results indicate that resource potential this is the only work to consider the effect of post-Triassic burial and post-Cretaceous exhumation, uplift and erosion across the basin. The importance of missing stratigraphy is often overlooked in many basin models, and in the case of the Bowland Basin has been completely ignored by previous work, e.g. Andrews (2013) and Whitelaw et al. (2019). Such events have the potential to significantly reduce the resource potential of many prospective unconventional and conventional hydrocarbon plays and must be considered during analysis. Our results also indicate that the volume of in-place conventional resources within reservoir intervals (Mercia Mudstone, Sherwood Sandstone and Kinderscout grit)were also significantly affected by post-Cretaceous exhumation. GIP estimates within reservoirs decrease by $\sim 30-50 \%$ as a result of post-Cretaceous uplift, exhumation and erosion (Figure 8). This decrease is most notable within the Sherwood Sandstone, where accumulations decrease by $60-70 \%$.

The geological complexity of the Bowland Basin cannot be understated. The area evaluated in this study contains 18 modelled faults, but in reality contains a much greater and unknown number of near-vertical faults below seismic resolution. Reactivation of unknown faults is the primary cause of repeated events induced seismicity that ultimately led to the United Kingdom government to declare an indefinite moratorium on hydraulic fracturing and abandonment of operations in the Bowland Basin. Whilst the Bowland Shale possesses all of the geochemical qualities required for a high-quality hydrocarbon source rock, a combination of geological complexity, basin compartmentalisation and highly variable uplift, exhumation, erosion and paleo 
heat flow across a relatively short distance $(\sim 100 \mathrm{~km})$ renders the potential for economically recoverable reserves extremely low. However, these factors and the extensive coverage of the Bowland Shale across Northern England raise the interesting possibilities of potential future work exploring carbon storage and geothermal resources.

\section{Low-carbon resources}

Given the recent moratorium on hydraulic fracturing in the UK the emerging shale gas industry has been put on hold. A growing body of research indicates that shales preferentially adsorb up to 7 times more $\mathrm{CO}_{2}$ than $\mathrm{CH}_{4}$ at similar temperatures and pressures (e.g. Ansari et al., 2018). Adsorption of $\mathrm{CO}_{2}$ to the surface of the host rock and desorption of the in-place $\mathrm{CH}_{4}$ has several potential advantages over conventional carbon storage methods in shales, namely that adsorbed $\mathrm{CO}_{2}$ remains fixed and does not dissolve into mobile fluids. This gives rise to the possibility that $\mathrm{CO}_{2}$ injection into shales could displace $\mathrm{CH}_{4}$, providing a means to reduce anthropogenic carbon and produce a commercial resource capable of being used as domestic fuel or as a source of hydrogen (e.g. (Busch et al., 2008; Liu et al., 2019)). However, the technique of enhanced $\mathrm{CO}_{2}$ shale gas recovery is still in an early stage and must be investigated as a potential means to produce low-carbon resources in Northern England. Despite the shale gas resource estimate from this and other recent studies being significantly lower than previous estimates, the possibility of simultaneously storing $\mathrm{CO}_{2}$ storage whilst producing natural gas resource from the naturally-fractured Bowland Shale presents an intriguing possibility for reducing the United Kingdom's anthropogenic emissions whilst and producing economic resources.

\section{Geothermal resources}

Present day heat flow measurements from the Bowland Basin are between $50-60 \mathrm{~mW} \mathrm{~m}^{-2}$ in its centre and $>70 \mathrm{~mW} \mathrm{~m}^{-2}$ in its northwest (Downing and Gray, 1986). Hydrogeological data from depth in the region is sparse. In the nearby Cheshire Basin, porosities of $20 \%$ are considered likely and intrinsic transmissivity is believed to exceed $9.910-12 \mathrm{~m}^{3}$. Temperature data are widely scattered on a temperature-depth plot, but suggest a geothermal gradient of $27^{\circ} \mathrm{C} \mathrm{km}^{-1}$. Maximum temperatures at the base Permian are predicted to be almost $100^{\circ}$ and at the base Sherwood Sandstone in excess of $80^{\circ} \mathrm{C}$. A corrected BHT of $81^{\circ} \mathrm{C}$ was measured at a depth of $3601 \mathrm{~m}$ in the

Prees borehole within the basal Permian breccias. These high temperatures 
only occur over a few square kilometers, but temperatures in excess of $50^{\circ} \mathrm{C}$ are found over large areas creating a large geothermal resource (Busby, 2014). Furthermore, the fact that the Sherwood Sandstone reaches a maximum thickness of $\sim 1500 \mathrm{~m}$ and has widespread coverage across Northern England and the Midlands raises the possibility of potential geothermal reservoirs that warrant further investigation (British Geological Survey, 1999).

\section{Conclusion}

Apatite fission track analyes indicates peak paleo temperatures of $90-$ $100^{\circ} \mathrm{C}$ occurred within the Sherwood Sandstone during Late Cretaceous times at well Hesketh-1. Application of this constraint to wells across the basin and $1 \mathrm{D}$ basin modelling indicate Late Cretaceous heat flow values of $62.5-$ $80 \mathrm{~mW} \mathrm{~m}^{2}$ and the erosion of $800-1500 \mathrm{~m}$ post-Triassic strata. The cause of elevated Late Cretaceous heat flow remains unresolved, however is likely related to igneous intrusive activity within the larger East Irish Sea Basin, which the Bowland Basin forms part of.

We apply analysis of biostratigraphic data, apatite fission track and 1D basin modelling of wells within the Bowland Basin to constrain a regional 2D basin model and estimate hydrocarbon resource potential. Our results indicate that the Bowland Shale reached maximum burial during the Late Cretaceous and the basin was subsequently exhumed and $<1500 \mathrm{~m}$ of postTriassic strata were removed. Hydrocarbon generation in the Upper and Lower Bowland shale commenced during Westphalian and Brigantian times, respectively. A secondary phase of hydrocarbon generation primarily within the Upper Bowland Shale occurred during Cretaceous times up to the time of maximum burial. Post-Cretaceous uplift, exhumation and erosion across the basin reduced gas in place by $<50 \%$. Our results indicate that the shale gas resource potential of the Bowland Basin varies between $4.7-6.7$ TCF and is significantly lower than previous estimates obtained by regional mapping across Northern and Central England. Finally, we conclude that the geological and structural complexity of the Bowland Basin render the region unsuitable for economic resources.

\section{Acknowledgements}

This work was completed as part of the Natural Envinonment Research Council-funded Unconventional Hydrocarbons in the UK Energy System 
(UKUH) project, grant number NE/R018065/1. Special thanks are given to Kelly Gallagher (University of Rennes) for access to QTQt thermochronological modelling software and Paul Green (Geotrack Ltd.) for providing apatite fission track data and expertise. Thanks is also given to Malcolm Butler (Beneath Britain) for providing access to regional seismic data. Recognition is given to the British Geological Survey for providing access to resources and workspaces that were essential for this work. Thanks is also given to Kieran Blacker for assistance with processing seismic data and discussions.

\section{References}

Allen, P.A.P.A., Allen, J.R., 2005. Basin Analysis - Principls and Application. doi:10.1017/CBO9781107415324.004, arXiv:arXiv:1011.1669v3.

Anderson, I., Underhill, J.R., 2020. Structural constraints on Lower Carboniferous shale gas exploration in the Craven Basin, NW England. Petroleum Geoscience, petgeo2019-125doi:10.1144/petgeo2019-125.

Andrews, I., 2013. The Carboniferous Bowland Shale gas study: geology and resource estimation. British Geological Survey Department of Energy and Climate Change URL: https://www.gov.uk/government/publications/bowland-shale-gas-study, doi:10.1016/j.marpetgeo.2013.03.016.

Ansari, H., Joss, L., Trusler, M., Maitland, G., Delle Piane, C., Pini, R., 2018. Enhanced Shale Gas Recovery: Gas Sorption Controls on Recoverable Gas and CO2 Storage Capacity, in: 14th International Conference on Greenhouse Gas Control Technologies, GHGT-14, pp. 1-9. doi:10.2139/ssrn.3365806.

Arthurton, R.S., 1983. The skipton rock fault - an Hercynian wrench fault associated with the Skipton Anticline, northwest England. Geological Journal 18, 105-114. doi:10.1002/gj.3350180202.

Arthurton, R.S., 1984. The Ribblesdale fold belt, NW England-a Dinantianearly Namurian dextral shear zone. Geological Society Special Publication 14, 131-138. doi:10.1144/GSL.SP.1984.014.01.13.

Bray, R.J., Green, P.F., Duddy, I.R., 1992. Thermal history reconstruction using apatite fission track analysis and vitrinite reflectance: A case study 
from the UK East Midlands and Southern North Sea. Geological Society Special Publication 67, 3-25. doi:10.1144/GSL.SP.1992.067.01.01.

British Geological Survey, 1999. 1:50,000 scale geological map sheet (England and Wales series) no 37.

Busby, J., 2014. Geothermal energy in sedimentary basins in the UK. Hydrogeology Journal 22, 129-141. doi:10.1007/s10040-013-1054-4.

Busch, A., Alles, S., Gensterblum, Y., Prinz, D., Dewhurst, D.N., Raven, M.D., Stanjek, H., Krooss, B.M., 2008. Carbon dioxide storage potential of shales. International Journal of Greenhouse Gas Control 2, 297-308. doi:10.1016/j.ijggc.2008.03.003.

Charsley, T.J., 1984. Early Carboniferous rocks of the Swinden No. 1 Borehole, west of Skipton, in: British Geological Survey Report No. 1611. British Geological Survey, pp. 5-12.

Clarke, H., Turner, P., Bustin, R.M., Riley, N., Besly, B., 2018. Shale gas resources of the Bowland Basin, NW England: a holistic study. Petroleum Geoscience 24, 287-322. doi:10.1144/petgeo2017-066.

Collinson, J., 1988. Controls on Namurian sedimentation in the Central Province basins of northern England, in: Sedimentation in a synorogenic basin complex. The Upper Carboniferous of Northwest Europe, pp. 85-101.

Corfield, S.M., Gawthorpe, R.L., Gage, M., Fraser, A.J., Besly, B.M., 1996. Inversion tectonics of the Variscan foreland of the British Isles. Journal of the Geological Society 153, 17-32. doi:10.1144/gsjgs.153.1.0017.

Dewey, J., 1982. Plate tectonics and the evolution of the British Isles. Journal of the Geological Society, London 1, 371-412. doi:10.1144/gsjgs.139.4.0371.

Donnelly, L.J., 2006. A review of coal mining induced fault reactivation in Great Britain. Quarterly Journal of Engineering Geology and Hydrogeology 39, 5-50. doi:10.1144/1470-9236/05-015.

Downing, R.A., Gray, D.A., 1986. Geothermal resources of the United Kingdom. Journal of the Geological Society 143, 499-507. doi:10.1144/gsjgs.143.3.0499. 
Earp, J., Poole, E., Whiteman, A., 1961. Geology of the country around Clitheroe and Nelson. volume 68. HM Stationery Office.

Falcon, N., Kent, P., 1960. Geological results of petroleum exploration in Britain, 1945-1957. Geological Society of London .

Fraser, A., Gawthorpe, R.L., 2003. Palaeogeography and facies evolution, in: An Atlas of Carboniferous Basin Evolution in Northern England. Geological Society, London, Memoirs, 28. chapter 4, pp. 27-49.

Fraser, A.J., Gawthorpe, R.L., 1990. Tectono-stratigraphic development and hydrocarbon habitat of the Carboniferous in northern England. Geological Society Special Publication 55, 49-86. doi:10.1144/GSL.SP.1990.055.01.03.

Gallagher, K., 2012. Transdimensional inverse thermal history modeling for quantitative thermochronology. Jorunal of Geophysical Research 117, 116. doi:10.1029/2011JB008825.

Gawthorpe, R.L., 1986. Sedimentation during carbonate ramp-to-slope evolution in a tectonically active area: Bowland Basin (Dinantian), northern England. Sedimentology doi:10.1002/9781444304473.ch31.

Gawthorpe, R.L., 1987. Tectono-sedimentary evolution of the Bowland Basin, N England, during the Dinantian. Journal of the Geological Society 144, 59-71. doi:10.1144/gsjgs.144.1.0059.

Green, P., Bray, R., 1992. East Irish Sea Basin: Thermal and tectonic development and hydrocarbon generation assessed using apatite fission track analysis and vitrinite reflectance Phase 2. Technical Report GC402.

Green, P., Duddy, I., Bray, R., 1995. Applications of Thermal History Reconstruction in inverted basins, in: Buchanan, J.G., Buchanan, P. (Ed.), Basin Inversion. Geological Society of London. 88, pp. 149-165.

Green, P.F., Duddy, I.R., Bray, R.J., 1997. Variation in thermal history styles around the Irish Sea and adjacent areas: Implications for hydrocarbon occurrence and tectonic evolution. Geological Society Special Publication 124, 73-93. doi:10.1144/GSL.SP.1997.124.01.06.

Green, P.F., Duddy, I.R., Hegarty, K.A., 2002. Quantifying exhumation from apatite fission-track analysis and vitrinite reflectance data: 
Precision, accuracy and latest results from the Atlantic margin of NW Europe. Geological Society Special Publication 196, 331-354. doi:10.1144/GSL.SP.2002.196.01.18.

Green, P.F., Thomson, K., Hudson, J.D., 2001. Recognition of tectonic events in undeformed regions: Contrasting results from the Midland Platform and East Midlands Shelf, Central England. Journal of the Geological Society 158, 59-73. doi:10.1144/jgs.158.1.59.

Gross, D., Sachsenhofer, R.F., Bechtel, A., Pytlak, L., Rupprecht, B., Wegerer, E., 2015. Organic geochemistry of Mississippian shales (Bowland Shale Formation) in central Britain: Implications for depositional environment, source rock and gas shale potential. Marine and Petroleum Geology 59, 1-21. URL: http://dx.doi.org/10.1016/j.marpetgeo.2014.07.022, doi:10.1016/j.marpetgeo.2014.07.022.

Guion, P., Gutteridge, P., Davies, S., 2000. Carboniferous sedimentation and volcanism on the Laurussian margin, in: Woodcock, N., Strachan, R. (Eds.), Geological History of Britain and Ireland. Blackwell Science, Oxford, pp. 227-271.

Hantschel, T., Kauerauf, A., 2009. Fundamentals of Basin and Petroleum Systems Modeling. Springer.

Holford, S.P., Turner, J.P., Green, P., 2005. Reconstructing the Mesozoic-Cenozoic exhumation history of the IrishSea basin systemusingapatitefission track analysis and vitrinite reflectance data, in: Dore, A., Vining, B. (Eds.), Petroleum Geology: North-West Europe and Global Perspectives - Proceedings of the 6th Petroleum Geology Conference. 1 ed.. Geological Society, London, pp. 1095-1107.

Holford, S.P., Turner, J.P., Green, P.F., Hillis, R.R., 2009. Signature of cryptic sedimentary basin inversion revealed by shale compaction data in the Irish Sea, western British Isles. Tectonics 28. doi:10.1029/2008TC002359.

Immenhauser, A., 2009. Estimating palaeo-water depth from the physical rock record. Earth-Science Reviews 96, 107-139. doi:10.1016/j.earscirev.2009.06.003. 
Ketcham, R.A., Carter, A., Hurford, A.J., 2015. Inter-laboratory comparison of fission track confined length and etch figure measurements in apatite. American Mineralogist 100, 1452-1468. doi:10.2138/am-2015-5167.

Liu, D., Li, Y., Yang, S., Agarwal, R.K., 2019. CO2 sequestration with enhanced shale gas recovery. Energy Sources, Part A: Recovery, Utilization, and Environmental Effects 0, 1-11. URL: 10.1080/15567036.2019.1587069, doi:10.1080/15567036.2019.1587069.

McDannell, K.T., Pinet, N., Issler, D.R., 2021. Exhuming the Canadian Shield: preliminary interpretations from low-temperature thermochronology and significance for the sedimentary succession of the Hudson Bay Basin. GSC Bulletin .

Nantanoi, S., Rodríguez-Pradilla, G., Verdon, J., 2021. 3D-seismic interpretation and fault slip potential analysis from hydraulic fracturing in the Bowland Shale, UK. Petroleum Geoscience, petgeo2021-057URL: https://doi.org/10.1144/petgeo2021-057, doi:10.1144/petgeo2021057 .

Palci, F., Fraser, A.J., Neumaier, M., Goode, T., Parkin, K., Wilson, T., 2020. Shale oil and gas resource evaluation through 3D basin and petroleum systems modelling: a case study from the East Midlands, onshore UK. Petroleum Geoscience 26, 525-543. doi:10.1144/petgeo2019-069.

Pharaoh, T.C., Gent, C.M., Hannis, S.D., Kirk, K.L., Monaghan, A.A., Quinn, M.F., Smith, N.J., Vane, C.H., Wakefield, O., Waters, C.N., 2018. An overlooked play? Structure, stratigraphy and hydrocarbon prospectivity of the Carboniferous in the East Irish Sea-North Channel basin complex. Geological Society Special Publication 471, 281-316. doi:10.1144/SP471.7.

Timmerman, M.J., 2004. Timing, geodynamic setting and character of Permo-Carboniferous magmatism in the foreland of the Variscan Orogen, NW Europe. Geological Society Special Publication 223, 41-74. doi:10.1144/GSL.SP.2004.223.01.03.

Torsvik, T., Carlos, D., Mosar, J., Cocks, L., Malme, T., 2002. Global reconstructions and North Atlantic paleogeography 440 Ma to recent, in: 
BATLAS - Mid Norway Plate Reconstructions Atlas with Global and Atlantic Perspectives. Geological Survey of Norway, Trondheim, Norway, pp. $18-39$.

Whitelaw, P., Uguna, C.N., Stevens, L.A., Meredith, W., Snape, C.E., Vane, C.H., Moss-Hayes, V., Carr, A.D., 2019. Shale gas reserve evaluation by laboratory pyrolysis and gas holding capacity consistent with field data. Nature Communications 10, 1-10. URL: http://dx.doi.org/10.1038/s41467-019-11653-4, doi:10.1038/s41467-019-11653-4.

Wygrala, B., 1989. Integrated study of an oil field in the southern Po basin, northern Italy (No. FZJ-2014-03033).

Yang, S., Horsfield, B., Mahlstedt, N., Stephenson, M., Könitzer, S., 2015. On the primary and secondary petroleum generating characteristics of the Bowland Shale, northern England. Journal of the Geological Society 173, 292-305. doi:10.1144/jgs2015-056. 